\title{
Rakım Farklılığı Nedeniyle Oluşan Meteorolojik Değişimlerin Su Kalitesine Olan Etkilerinin CBS ile Değerlendirilmesi: Morfolojik Olarak Farklı İki Göl için Bir Karşılaştırma
}

\author{
Hüseyin CÜCE ${ }^{1 *}$, Erkan KALIPCI ${ }^{2}$, Beyhan TAŞ ${ }^{3}$, Muhammet YILMAZ ${ }^{4}$ \\ ${ }^{1,2}$ Giresun Üniversitesi, Mühendislik Fakültesi, Harita Mühendisliği Bölümü, Giresun \\ ${ }^{3}$ Ordu Üniversitesi, Fen Edebiyat Fakültesi, Moleküler Biyoloji ve Genetik Bölümü, Ordu \\ ${ }^{4}$ Nevşehir Hacı Bektaş Veli Üniversitesi, Mühendislik-Mimarlık Fakültesi, Çevre Mühendisliği Bölümü, Nevşehir
}

*Sorumlu Yazar: huseyin.cuce@giresun.edu.tr

Geliş Tarihi: 20.11.2019

Kabul Tarihi: 12.12 .2019

\section{Öz}

Bu çalışmada doğal ve yapay su kaynaklarının su kalitesini etkileyen etkenlerden birisi olarak saptanan deniz seviyesine olan yükseklikten kaynaklı meteorolojik değişimlerin CBS ortamında bir değerlendirmesi yapılmıştır. Ordu İli sınırları içerisinde 68 m rakıma sahip Gaga Gölü Sulak Alanı'nın ve 1732 m rakıma sahip Çambaşı Göleti’nin fiziksel ve kimyasal su kalitesi değerlerinin karşılaştırılması ve iki çalışma noktası arasındaki rakım farkının bu su ekosistemlerinin su kaliteleri üzerindeki etkileri mekânsal olarak analiz edilmiştir. Göllerdeki yüzey suyu kalitesinde oluşabilecek etkilerin daha iyi anlaşılabilmesi için 3 mevsim sürdürülen ölçüm çalışmalarından elde edilen bulgular dağılım haritaları vasıtasıyla karşılaştırılmıştır. Tüm veri analizi sonuçlarıyla beraber her iki su ekosisteminin bulunduğu bölge arasındaki meteorolojik, ekolojik ve sosyolojik farklılıklar göz önüne alınarak çevre kalite standartlarında görülen etkilerin değerlendirmesi yapılmış ve bölgeye özgü yoğun mevsimsel geçişler yaşanması nedeniyle bazı fiziko-kimyasal parametrelerin olumsuz yönde etkilendiği görülmüş̧ür. Çalışmanın son bölümünde arazi kullanım farkı, noktasal ve yayılı kirletici kaynaklara olan yakınlığın oluşturduğu trofik düzeydeki değişimlerin sonuçları tartışılmış ve Yerüstü Su Kalitesi Yönetmeliği çerçevesinde sınıflandırma kriterleri göz önüne alınarak bu su kaynaklarının daha verimli kullanımı, korunması ve sürdürülebilir yönetimi konusunda bazı öneriler geliştirilmiştir.

Anahtar Sözcükler: Su kalitesi, Göl, Sulak alan, CBS, Konumsal analiz

\section{Evaluation of the Impacts on Water Quality from Meteorological Changes Due to Differences in Altitude by GIS: A Comparison for Two Morphologically Different Lakes}

\begin{abstract}
In this study, an assessment of the meteorological changes of natural and artificial water resources due to elevation to sea level, which is determined as one of the factors affecting water quality, is made in GIS environment. The comparison of physical and chemical water quality values of Gaga Lake Wetland with $68 \mathrm{~m}$ altitude and Çambaşı Pond with $1732 \mathrm{~m}$ altitude in Ordu province and the effects of altitude difference between two study points on water quality of these ecosystems were spatially analyzed. In order to better understand the effects of surface water quality in the lakes, the results obtained from the 3 seasons measurement studies were compared with the distribution maps. With all data analysis results, assessment of environmental quality standarts was made by considering the meteorological, ecological and sociological differences between of the regions where both water ecosystems are located and it was found that some physico-chemical parameters were negatively affected due to the intense seasonal transitions. In the last part of the study, results of differences in land use, trophic changes caused by proximity to point and diffuse pollutant sources are discussed. And also some suggestions have been developed for the sustainable management, protection and more efficient use of these water resources by taking into consideration the classification criteria within the framework of the Regulation on Surface Water Quality.
\end{abstract}

Keywords: Water quality, Lake, Wetland, GIS, Spatial analyst 


\section{Giriş}

Dünyanın \% 70'i sularla kaplıyken bu miktarın çok az bir kısmını tatlı sular oluşturmaktadır. İçme ve kullanma suyu olarak tatlı sulardan yararlanılmakta ve bu durum kullanılabilir su kaynaklarının hızla azalmasına neden olmaktadır. Dünyada hızla artan nüfus, endüstrileşme, bilinçsiz tüketim vb. nedenden dolayı su tüketimi hızla artmaktadır. Su tüketiminin çoğu doğal göllerden, yapay göl ve göletlerden sağlanmakta ancak yetersiz kalınan durumlarda nehir, 1rmak ve dere gibi yerüstü sularından ve sulak alanlardan karşılanmaktadır. Doğal göller veya sulak alanlar gibi yapay göller, göletler veya sulak alanlar da oluşumlarından itibaren kendi ekosistemlerini kurmakta ve yaşam döngüsünü sağlamaktadır. Göller, sulak alanlar veya göletler ister yapay olsun ister doğal, yaşam döngüsünü sağlamak ve ekosistemin sürdürülebilirliği için su kalitesinin istenilen ve döngüye yetebilen miktarda madde ve parametreleri sağlaması gerekmektedir.

Günümüzde, yüzey su kalitesinin bozulması ve göl ötrofikasyonunun kontrolü kritik bir problemdir. (Raicevic vd., 2011). Ülkemizdeki doğal göller ve sulak alanlarda karşılaşılan başlıca sorunlar; su miktarındaki azalmalar, biyolojik çeşitliliklerin tehdit altında olması ve su kaynaklarına olan aşırı nutrient girişi vb. gösterilebilir. Özellikle sulak alan ve sığ göllere nutrient artışına olan ekolojik tepkilerin (ötrofikasyon gibi) büyüklügünün ve yöneliminin tahmin edilmesi dolayısıyla bu kaynakların yönetilmesi zordur (Pusceddu, 2007). Genellikle, ötrofikasyon yüzey suyunda doğal bir proses olarak görünse de, su havzalarından ve diğer insan kökenli kaynaklardan gelen dişsal girdiler bu önemli sorunun başlıca etkenleridir (Tsagli, 2006).

Doğal su kaynaklarının, hızla artan nüfus ve endüstrileşme sonucunda azalması hatta kirletilerek kontrolsüz bir şekilde doğaya deşarj edilmesi var olan sucul ekosistemlerinin de kullanılamaz hale gelmesine neden olmaktadır. Buna bağlı olarak su ve sedimanda biriken kirleticiler fiziksel, kimyasal ve biyolojik proseslerin bir sonucu olarak besin zincirinde depolanabilir veya serbest kalarak üzerindeki su kolonuna geçerek kalitesini bozabilir (Bakan, 1995; EC,2000). Göllerin; sürdürülebilir su kaynakları yönetimindeki boşlukların olması, göl havzalarında insan faaliyetleri, kentsel, tarımsal ve sanayi atıklarından kaynaklanan sebepler dolayısıyla su kalitesinin bozulmasının kontrol altına alınması gerekmektedir (OSİB, 2017). Su kaynaklarının hızlı bir şekilde kirletilmesi ve azalması insanları yeni su kaynakları bulmaya yöneltmiştir. Dolayısıyla, pek çok akarsu havzalarına yapay göletler inşa ederek gerek yüzeysel akışlardan gerekse atmosferik su döngüsünden yağmurlardan yararlanılarak gölet doldurulmaya çalışılmaktadır, ancak inşa edilen bu yapay göletlerin içme-kullanma veya sulamaya yönelik su kalitesini de sağlaması gerekmektedir. Göl ve/veya gölet gibi su kaynaklarının kontrolü ve yönetimi, su kütlesi ve onu çevreleyen bölge arasındaki karışık etkileşimlerin (rakım farkı, 
meteorolojik faktörler, arazi kullanımındaki değişikliler, kirletici kaynaklara olan yakınlık gibi) analiz edilmesini gerektirir (Christophoros ve Fytianos, 2006).

Göllerin veya sulak alanların su kalitesini belirleyen pek çok organik ve inorganik kirleticilerden kaynaklı parametreler bulunmaktadır. Bu kirletici parametrelerin göllere veya sulak alanlara karışımının birçok yolu bulunmakta ve bu kirleticilerin sucul ortama geçişini etkileyen çeşitli faktörler bulunmaktadır. Kirleticilerin kaynağından çıkış ve sucul ortama geçişine kadar olan süreçte bölgenin iklimsel (sıcaklık, yağışlar vb.), coğrafik (bitki örtüsü, yeryüzü şekli vb.), jeolojik (toprakta bulunan maddeler, toprağın cinsi, toprağın sızdırma ve çözünme özelliği vb.), atmosferik (basınç değişimi, havadaki gazların taşınım oranı vb.) özellikleri kirleticilerin sucul ortama geçişini artırma veya azaltma yönünde etkilemektedir. Bu özelliklerin hepsinin ortak paydada buluştuğu ve bu özelliklerin değişim göstermesini sağlayan faktörlerden biri yükseklik yani bölgenin deniz seviyesine olan mesafesidir.

Deniz seviyesinden yüksek (dağlık alanlar gibi) sistemlerde, karmaşık topoğrafya, sert iklim koşulları ve kısa süren büyüme sezonları vb. hakim koşullar olduğundan özellikle bu alanlardaki toprağın ve yüzey su kaynaklarının fiziko-kimyasal yapılarının muhafaza edilmesi ve biyolojik toplulukları etkileyen süreçlere karşı konulması güçleşir. Yüksek rakım iklimsel değişimler yanında dış kaynaklı kirletici ve nütrient girdilerine karşı savunmasız bir ekosistem oluşturur (Baron ve ark., 2009). Yine, bozulmamış, referans nokta özelliği taşıyan dă̆ göllerinin ekolojik özelliklerinin belirlenmesi, gelecekte ne tür değişimin olduğunu görmek açısından oldukça önemlidir (Taş, 2016). Deniz seviyesinden yüksek bölgelere çıkıldıkça birçok alanda (iklimsel, oksijen miktarı, atmosfer basıncı, ekolojik farklılık, insan yaşamı) değişimler gözlenmektedir. Bu değişimler kalitatif ve kantitatif olarak gözlemlenebilir ve fark edilebilir sonuçlar ortaya konulabilmektedir. Rakım yükseldikçe iklim koşulları farklılaşır. Bunun sebebi artan rakımın sıcaklık, nem, yağış, radyasyon ve rüzgar gibi iklim elemanları üzerindeki etkileridir. Aynı enlemde bulunan farklı yükseklikteki alanlarda farklı sıcaklıklar görülmekte olup deniz seviyesinden yükseğe çıktıkça her $100 \mathrm{~m}$ kuru havada sıcaklık $1^{\circ} \mathrm{C}$, nemli havada $0.6^{\circ} \mathrm{C}$ düşmektedir. Yüksek rakımda gece gündüz arası sıcaklık farkları yüksektir. Her yüz metrelik rakım artışında atmosfer sıcaklığında $0.6^{\circ} \mathrm{C}$ azalma gözlenmektedir. Ilıman iklim kuşağında, her hangi bir ekolojide rakımın artması sonucu atmosfer sıcaklığı azalmakta ve yağış miktarı artmaktadır. Hava akımı yüksek rakımlı bölgelerden geçerken taşımış olduğu nemin büyük bir kısmını yağış şeklinde bırakmaktadır. Işsık göl ekosistemi için önemli bir yere sahip olup göl içerisindeki canlı yaşamını etkileyen bir faktördür. Yüksek rakımlı yerlerde 1şık yoğunluğu ve güneş radyasyonu artar. Küçük ve yumuşak pigmentsiz canlılar 1şıktan korunmak için suyun alt tabakalarına göç ederler. Çünkü dip ortamda yaşayan canlıların yumurtaları 1şık, UV, floresans ile direkt etkilenir. Yüksek rakımda gece sıcaklıklarının düşük olması sonucunda bitkiler gündüz ürettikleri fotosentez ürünlerini, gece uygun sıcaklık olmadığı 
için daha az tüketirler. Gece sıcaklığının yüksek olduğu yerlerde gündüz üretilen fotosentez ürünlerinin büyük bir kısmı gece tüketilmektedir (Güner, 2011; KUDAKA, 2016).

$\mathrm{Bu}$ çalışmada rakım farkının etkilediği çevresel, iklimsel ve coğrafik şartların, ekolojik olarak önemli yüzey suları olan farklı morfolojik yapıdaki iki lentik sistemin çeşitli su kalite parametrelerinin göstermiş olduğu farkl1lıklar incelenerek ve Coğrafi Bilgi Sistemi (CBS) ortamında tematik haritalandırma yöntemiyle verilerin karşılaştırılması yapılmıştır. Böylelikle, yüksek rakımlı veya düşük rakımlı bölgelerde hava ve toprak kirliliğinin basınç, sıcaklık gibi meteorolojik etkenlerin altında göllerin su kalitesini nasıl etkilediği incelenmiştir. Örnek çalışma alanı olarak Ordu ili Fatsa ilçesinde bulunan Gaga Gölü Sulak Alanı (rakım 68 m) ve Ordu ili Kabadüz ilçesinde Çambaşı Yaylası mevkiinde bulunan Çambaşı Göleti (rakım 1732 m) seçilmiştir.

\section{Materyal ve Yöntem}

Çalışma iki aşamadan meydana gelmektedir. Birinci aşamada, çalışma alanları olarak seçilen aynı bölgede fakat farklı rakımlarda yer alan iki gölde; Gaga Gölü Sulak Alanı ve Çambaşı Göleti coğrafik özellikleri hakkında genel bir araştırma yapılmış ve literatürde yer alan bilgiler derlenmiştir. Çalışma alanı olarak seçilen Gaga Gölü Sulak Alanı ve Çambaşı Göleti; Karadeniz Bölgesi Ordu il sınırları içerisinde bulunmaktadır (Şekil 1a). İki göl arasındaki rakım farkı 1664 m'dir (Şekil 1b). Gaga Gölü Sulak Alanı su kalitesi parametreleri analiz sonuçları için Candan (2011) tarafından sonuçlandırılmış tez araştırma bulguları, Çambaşı Göleti su kalitesi parametreleri analiz verileri ise Topkara'nın 2011 yılında yapmış olduğu tez çalışması bulgularından elde edilmiştir. İki gölde kalite karşılaştırması yapabilmek ve sucul ortamda meydana gelen değişimleri ortaya koyabilmek için bu çalışmada kullanılan tüm veriler mevsimsel olarak (ilkbahar karışım sezonu, yaz büyüme dönemi ve sonbahar karışım sezonu) derlenmiştir. Örnekleme noktalarının koordinatları, rutin parametre analizleri; sıcaklık, çözünmüş oksijen, pH, iletkenlik, TÇM, toplam sertlik, sülfat $\left(\mathrm{SO}_{4}\right)$, amonyum $\left(\mathrm{NH}_{4}\right)$, nitrit $\left(\mathrm{NO}_{2}\right)$, nitrat $\left(\mathrm{NO}_{3}\right)$, fosfat $\left(\mathrm{PO}_{4}\right)$, kalsiyum $\left(\mathrm{Ca}^{+2}\right)$, magnezyum $\left(\mathrm{Mg}^{+2}\right)$ ve klorofil-a analiz sonuçları bilgisayar ortamına aktarılarak maksimum, minimum ve ortalama değerler saptanmıştır. İkinci aşamada ise, ArcGis 10.5 paket programında her bir parametre için ortalama değer bazında tematik haritalandırma işlemi gerçekleştirilmiştir. Her iki göl için Shapefile dosyası Google Earth Pro programından alınan maksimum çözünürlükteki uydu görüntülerinin ArcMap ortamında işlenmesi ile hazırlanmıştır. Göllerin su kalitesi parametreleri (sıcaklık, çözünmüş oksijen, oksijen doygunluğu, pH, iletkenlik, TÇM, toplam sertlik, amonyum, nitrit, nitrat, sülfat, fosfor, kalsiyum, magnezyum) için tematik haritalar oluşturulmuştur. Tüm mekânsal analizler, Spatial Analyst modülü yardımıyla IDW-Ters mesafe ağırlıklı enterpolasyon tekniği ile kullanılarak yapılmış ve meteorolojik değişimlerin göllerin su kalitesi üzerinde yol açtığı 
etkileri karşılaştırmak için üretilen haritalar değerlendirilmiştir. IDW enterpolasyon tekniği, enterpole edilecek yüzeyde yakındaki noktaların uzaktaki noktalardan daha fazla ağırlığa sahip olması esasına dayandırılır ve örneklem, nokta verilerinden enterpolasyonla grid üretmede çoğunlukla tercih edilen ortak bir yöntemdir (Arslanoğlu ve Özçelik, 2005).

Çalışmanın son kısmında ise, göllerde morfolojik ve batimetrik farklılıkların yol açtığı yüzey suyu kalitesinde görülen iklime bağlı değişimler dikkate alınarak, deniz seviyesine olan yükseklik farkının gösterilebileceği doğrudan ve dolaylı etkiler tartışılmış, ayrıca sürdürülebilir su kaynakları yönetimi için önerilerde bulunulmuştur.
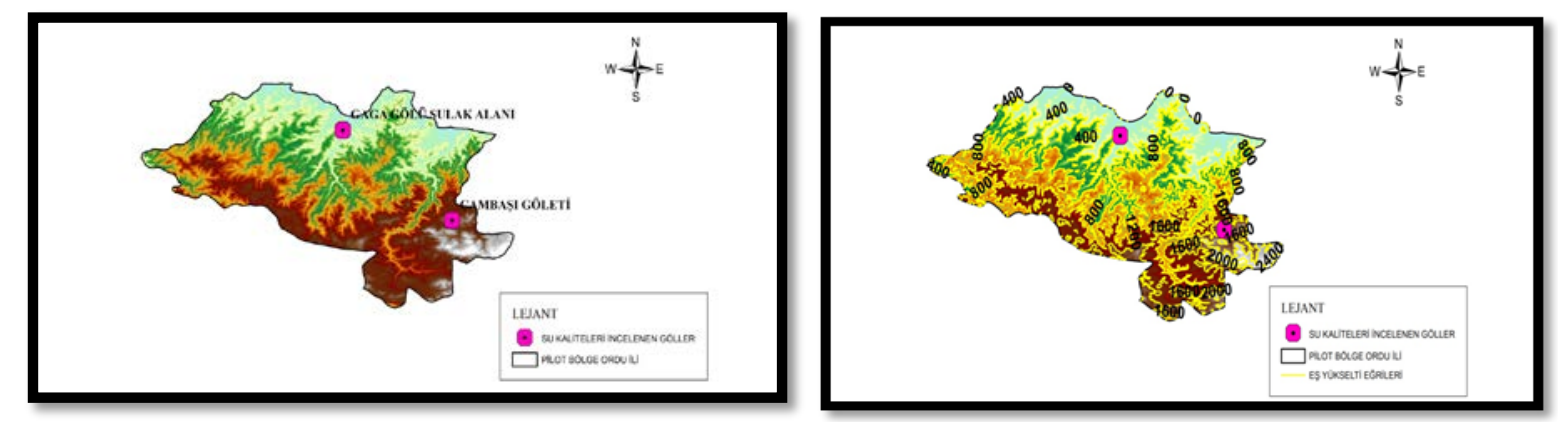

Şekil 1. Ordu ili sınırlarında araştırma yapılan noktalar ve yükselti haritası

\section{1. Çalışma Alanlarının Tanımı ve Özellikleri}

\subsubsection{Gaga Gölü Sulak Alanı}

4058'25.0" Kuzey - 37³0'01.1" Doğu koordinatlarında, Orta Karadeniz Bölgesi Ordu ili Fatsa ilçesi Bolaman Çayı Havzası'nda bulunan Gaga Gölü Sulak Alanı, adını aldığı Gaga Gölü’ne 30 m mesafede olup küçük su yollarıyla göle bağlanmaktadır (Şekil 2). Deniz seviyesinden 68 m

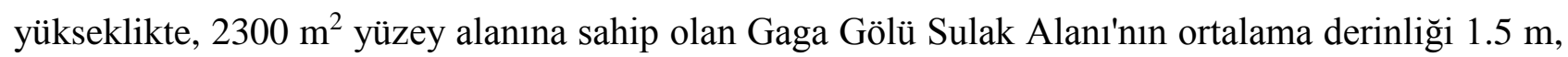
çapı 100 m kadardır. 


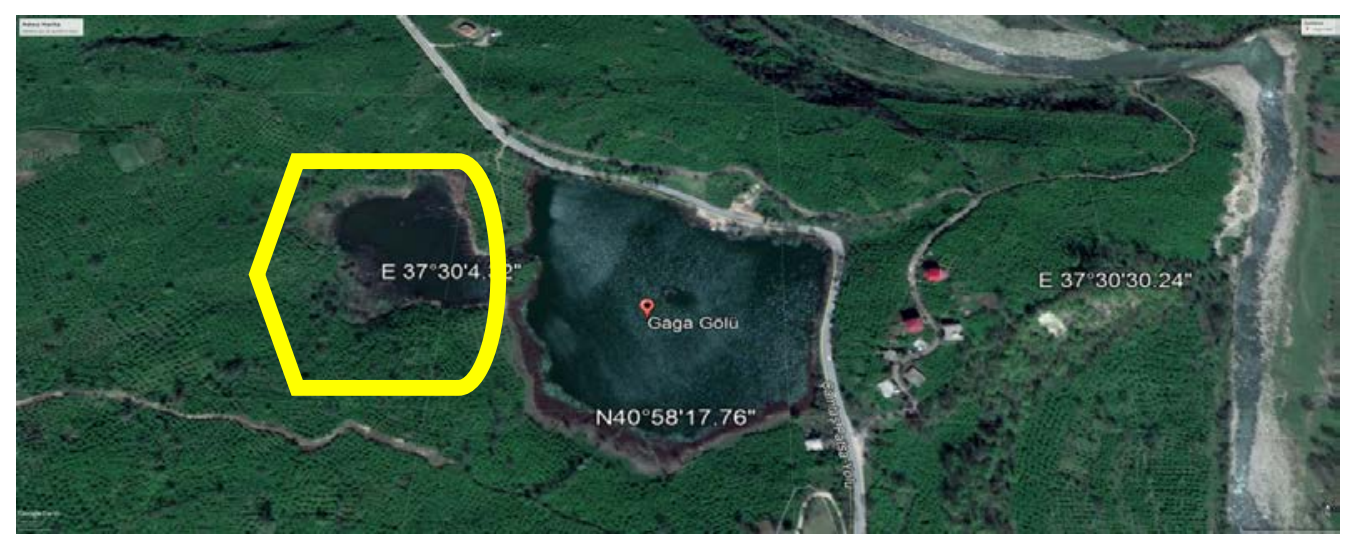

Şekil 2. Gaga Gölü Sulak Alanı’nın uydu görüntüsü

Gaga Gölü Sulak Alanı deniz seviyesine olan yüksekliğinin (68 m) az olması nedeniyle 1lıman ve dört mevsim yağış alan Karadeniz ikliminin etkisi altındadır. Bu nedenle sulak alan bol miktarda yağış alırken, yaz aylarının serin geçmesinden dolayı buharlaşma miktarı az olmaktadır. Genel anlamda sulak alan su seviyesini korumakta ancak çevresindeki tarım arazileri ve beşeri unsurlar nedeniyle ekolojik yapısı zamanla bozunuma uğramaktadır (Candan, 2011).

Gaga Gölü Sulak Alanı jeolojik yapısı: Üst Kretase-Paleosen; volkanitler, klastiklerden oluşan bir yapısal alan içerisinde bulunduğu görülmüştür (Şenel ve ark., 2001). Sulak alan, Fatsa-Çamaş Karayolunun 6. kilometresinde olup kara yoluna olan uzaklığı $150 \mathrm{~m}$ ve çevredeki yerleşim alanlarına olan mesafesi 200-450 m arasındadır.

Gaga Gölü Sulak Alanı çevresinde yoğun olarak findık tarım arazileri bulunmaktadır. Sulak alanı çevreleyen bu tarım arazileri doğal ve güzel bir yeşil alan görünümünde ancak bu güzel alanın diğer yüzünde, sulak alanın sucul ekosistemini ve su kalitesini kirleten zirai tarım ilaçları bulunmaktadır. Sulak alanın çevresinden gelen zirai temelli atıklar sucul ortamın azot ve fosfor dengesini bozma ve toksik madde bulunabilme veya miktarını artırabilme eğilimde olabilmektedir (Taş, 2012).Yerleşim alanları ve hayvancılık kaynaklı diğer bölgesel atıklar, yağışlar etkisiyle sızıntı ve/veya doğrudan sulak alanlara karışarak su kalitesini olumsuz yönde etkilemektedir.

\subsection{2. Çambaşı Göleti}

40³8'26.7" Kuzey - 3756'23.7" Doğu Orta Karadeniz Bölgesi Ordu ili Kabadüz ilçesi Çambaşı Yaylası mevkiinde bulunan Çambaşı Göleti, Kabalak Deresi üzerindedir (Şekil 3). Göletin çevresi $810 \mathrm{~m}$, yüzey alanı ise $20581 \mathrm{~m}^{2 \prime}$ dir. DSİ tarafından sulama amaçlı olarak gövdesi harç kargir betondan inşa edilmiş ve aktif göl hacmi yaklaşık $0,080 \mathrm{hm}^{3}$ olan bir gölettir (ÇŞB, 2017). Göletin bulunduğu bölgede 2010 yılında yapım çalışmaları başlayan ve 2017 yılında bir kısım sosyal tesisleriyle hizmete açılan Çambaşı Kayak Merkezi bulunmaktadır. 


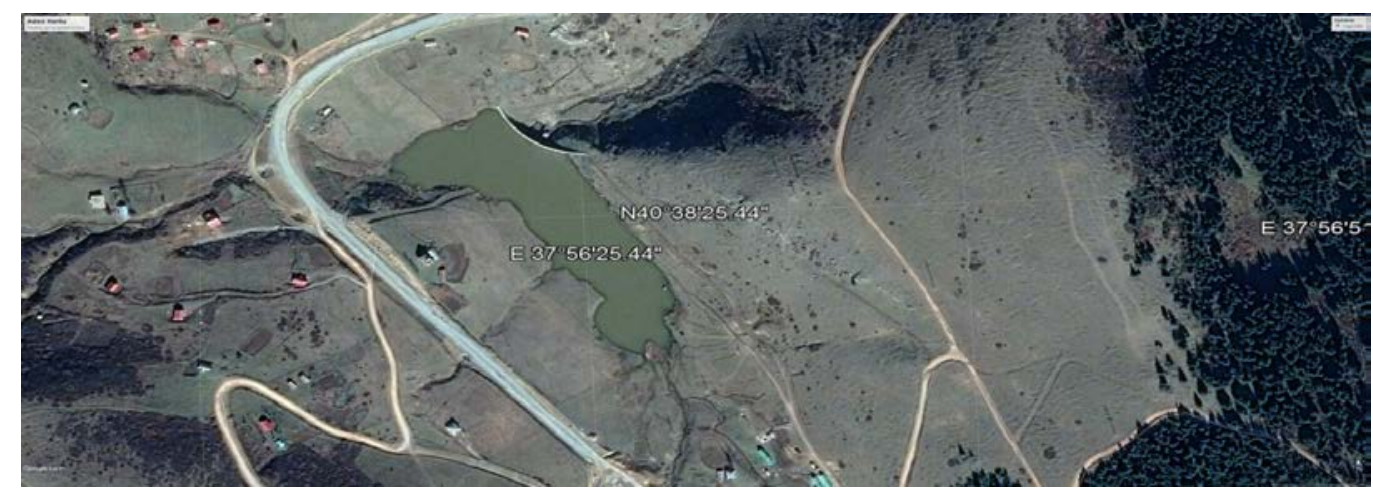

Şekil 3. Çambaşı Göleti'nin uydu görüntüsü

Çambaşı Göleti Karadeniz ikliminin hakim olduğu bir bölgede olduğundan dört mevsim yağış alır. Göletin deniz seviyesine olan yüksekliği 1732 m'dir. Bu nedenle yaz ve kış aylarındaki iklim özellikleri denize yakın mesafede olan bölgelerden farklılık gösterebilmektedir.

Çambaşı Göleti'nin kıyı şeridine göre daha yüksek olması nedeniyle kış mevsimleri daha soğuk geçmektedir. Yağışlar genelde kış ve ilkbahar aylarında etkili olmaktadır. Yükseltinin fazla olmasından dolayı yaz ayları serin geçmektedir. Kasım aylarının sonundan şubat ayının sonuna kadar yer yer kar yağışları gözlemlenmektedir. Aralık, ocak ve şubat aylarında göl ve çevresi karlarla kaplıdır. İlçenin iklimi, yüksekliği 2000 metreyi geçen Giresun Dağları'nın etkisinde kalmaktadır (Topkara, 2011).

Ordu ilinde hayvancılık yapanlar için mera alanı önemli bir sorundur. Ordu ilinde ana geçim kaynağının findık olması nedeniyle arazilerin çoğunluğu findık tarım arazisidir. Bu da mera alanı sorununu ortaya çıkarmaktadır. Çambaşı Göleti'nin bulunduğu yaylada yapılması planlanan mera alanı tahsis çalışmaları sonucunda bu alanlardan yüzeysel akışla gölete farklı özellikte kirleticilerin karışması muhtemeldir. Mera ıslah çalışmaları sonucu toprağa uygulanacak zirai ilaçlar ve suni gübre kaynaklı organik ve inorganik kirletici maddelerin yağışlarla birlikte göleti besleyen Kabalak ve Oba derelerine karışarak göletin kirlilik yükünü arttırması öngörülen bir sonuçtur.

Gaga Gölü Sulak Alanı su kalitesini tespit için yapılan önceki çalışmalar mevsimsel olarak bazı parametreler için artış olmakla birlikte her üç dönem için (ilkbahar, yaz ve sonbahar) ortalama değerler bazında önemli bir değişim göstermemektedir. Fakat mevsimsel olarak yaşanan bazı parametrelerdeki artışların nedenininhem değişen iklim koşulları hem de sulak alanı çevreleyen fındık tarım arazilerindeki mevsimsel bakım ve hasat çalışmalarının olduğu düşünülmektedir.

Çambaşı Göleti su kalitesi parametre analiz sonuçları, mevsimsel olarak çok büyük bir değişimin olmadığını göstermiştir. Çambaşı Göleti’nin su kalite analizinde bazı parametrelerin çok düşük çıkmasının nedeni gölün deniz seviyesinden 1732 m yüksekte olması ve bu durumun da göletin bulunduğu bölgenin iklim koşullarını, atmosfer basıncını, havada bulunan oksijen miktarını etkilemesidir. Bu durumun gölün su kalitesini de olumlu etkilediği görülmektedir. 


\section{Bulgular ve Tartışma}

\subsection{Rakımsal Fark Etkisinin Karşılaştırılması}

Gaga Gölü Sulak Alanı ve Çambaşı Göleti'nin bulunduğu bölgeler arasındaki rakım farkı $1664 \mathrm{~m}$ olup bu farktan dolayı bölgesel değişimler gözlenmektedir. Bazı fiziksel ve kimyasal su kalitesi parametreleri (sıcaklık, çözünmüş oksijen, oksijen doygunluğu, pH, iletkenlik, toplam çözünmüş katı madde (TÇM), toplam sertlik, amonyum-azotu, nitrit-azotu, nitrat-azotu, sülfat, ortofosfat, toplam fosfat, kalsiyum, magnezyum ve klorofil-a) üzerinde oluşan atmosferik ve ekolojik etkiler mevsimsel ve yıllık ortalama analiz sonuçlarının değişmesine neden olmaktadır.

\subsubsection{Sıcaklık Değeri}

Sıcaklık değeri göllerin ve sulak alanların yaşamsal döngülerine olan etkisinin yanında, fiziksel ve kimyasal birçok parametresini de doğrudan ya da dolaylı olarak etkilemektedir. Sicaklık değeri nasıl zincirleme reaksiyon başlatarak etkiler gösteriyorsa sıcaklık değerini de etkileyen bazı durumlar vardır.

Çalışma alanlarının bulundukları rakım farkı oldukça fazladır ve bu durumun göllerin sıcaklık değerlerini mevsimsel olarak etkilediği görülmüștür (Tablo 1). Gaga Gölü Sulak Alanı yüzey suyu yıllık ortalama sıcaklık değerinin $20.8^{\circ} \mathrm{C}$ (maksimum $30^{\circ} \mathrm{C}$ ile Temmuz ayı-yaz döneminde), Çambaşı Göleti yüzey suyu sıcaklığı ise $14.9^{\circ} \mathrm{C}$ (maksimum $21^{\circ} \mathrm{C}$ ile Ağustos ayı-yaz mevsiminde) olduğu görülürken, en düşük sıcaklıkların ise her iki gölde de ilkbahar başında, Mart ayında $8.3^{\circ} \mathrm{C}$ olduğu tespit edilmiştir. Yüksek kotta bulunan Çambaşı Göleti’nin tüm dönemlerde daha soğuk bir yüzey suyuna sahip olduğu söylenebilir. Çambaşı Göleti Turnasuyu Havzası'nın yukarısında bulunan ve havzayı besleyen bir lokalitede yer alır. Aşağı havzada yapılan bir çalışmada, subtropikal iklim kuşağında bulunan Türkiye'de son yıllarda yeterli yağışın düşmemesinin yerüstü sularının ekolojik yapısını olumsuz yönde etkilediği bildirilmiştir. Bununla birlikte, tarımsal ve evsel kaynaklı antropojenik etkilerin ilerleyen zamanda su kalitesini olumsuz yönde etkileyebileceği belirtilmiştir (Taş ve ark., 2019). Bu durum hem deniz seviyesinde hem de yüksek rakımlarda bulunan su kütleleri için geçerlidir. Çalışma alanlarında sıcaklık değişimi için oluşturulan dağılım haritası Şekil 4'te verilmiştir 
Tablo 1. Çalışma alanlarında mevsimsel sıcaklık değişiminin ort., min. ve maks. değerleri

\begin{tabular}{r|cccccc} 
Sicaklık [ ${ }^{\circ}$ C] & $\begin{array}{c}\text { GAGA GÖLÜ } \\
\text { SULAK ALANI } \\
\text { (rakım: } 68 \mathrm{~m} \text { ) }\end{array}$ & En Yüksek & En Düşük & $\begin{array}{c}\text { CAMBAŞI } \\
\text { GÖLETI (rakım: } \\
1732 \mathrm{~m})\end{array}$ & En Yüksek & En Düşük \\
\hline Ilkbahar & 16.97 & 25.7 & 8.3 & 10.13 & 12.6 & 8.3 \\
Yaz & 25.93 & 30 & 23.3 & 19.23 & 21 & 18.1 \\
Sonbahar & 19.50 & 26.1 & 11.2 & 15.40 & 17.8 & 13.4
\end{tabular}

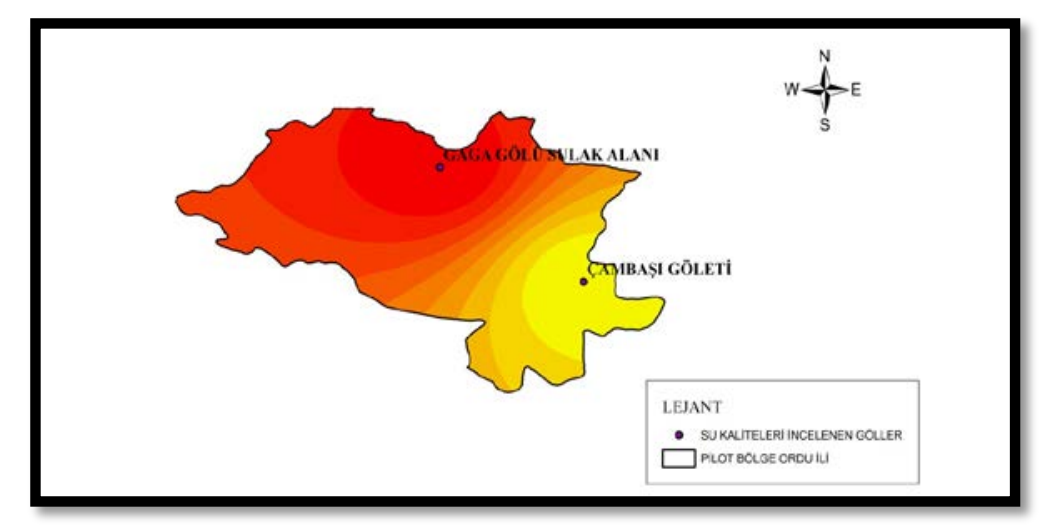

Şekil 4. Göllerde rakımsal farkın oluşturduğu sıcaklık dağılım haritası

Rakım farkı 1664 m olan bu iki çalışma alanının su sıcaklığı değerleri aylar bazında ölçülmüş ve mevsimsel olarak ortalama değerler saptanarak çalışma alanlarının mevsimsel sıcaklık farklarının ortalama $4^{\circ} \mathrm{C}$ ile $6^{\circ} \mathrm{C}$ arasında değişim gösterdiği gözlemlenmiştir. Göl suyunun sıcaklığ gölün coğrafi konumuna, derinliğine, alanına, erimiş madde miktarına, mevsimlere ve soğurulan enerjiye bağlı olarak değişir (Taş ve ark., 2010). Yine, suyun 1sınmasına etki eden faktörler arasında; doğrudan güneş 1şıması ve absorbsiyon, atmosferin 1sı iletkenliği, su yüzeyindeki su buharının yoğunlaşması, gel-git olayları ve yüzeyden esen rüzgârlar gösterilebilir.

\subsection{2. Çözünmüş Oksijen Değeri}

Göllerin ve sulak alanların su kalitesinde belirleyici parametrelerden birisi olan çözünmüş oksijen (ÇO) miktarı sucul ekosistem içerisinde yaşayan canlıların yaşamlarını devam ettirmesi için önemli bir yere sahiptir. Ayrıca su içerisinde bulunan organik maddeleri parçalayan aerobik mikroorganizmaların faaliyetlerini stabil düzeyde tutmak ve devam ettirmek ve suyun organik madde yükünü azaltmak için de önemlidir. ÇO miktarı suyun ekolojik kararlılığının çok önemli bir ölçütüdür (Taş ve Kolören, 2017). Göller ve sulak alanların ÇO miktarını doğrudan veya dolaylı olarak etkileyen birçok parametre bulunmaktadır. Bunlar genel olarak; su sıcaklığı (ters orantılı), su yüzeyinde atmosferik gazın kısmi basıncı (yükseklik ya da derinlik; doğru orantı11), suda çözünmüş tuz yoğunluğu (ters orantılı), su içinde gerçekleşen biyolojik olaylardır (Taş, 2006; Güner, 2011). 
Deniz seviyesinden yüksek rakımlı bölgelere çıkıldıkça basıncın azalması, havadaki oksijen miktarının azalması ve sıcaklığın azalması gibi etkenler sucul ortam içerisindeki ÇO miktarında dolaylı olarak yükseklik faktörünün de etkili olduğunu göstermektedir. Gaz çözünürlüğü sıcaklık ile önemli ölçüde değişir. Tatlı sularda çözünmüş oksijenin doygunluk değeri 1 atm hava basıncında ve $0^{\circ} \mathrm{C}$ 'de $14.6 \mathrm{mg} / \mathrm{L}$ 'den $35^{\circ} \mathrm{C}$ 'de $7 \mathrm{mg} / \mathrm{L}$ 'ye kadar düşer. Doygunluk, atmosferik oksijen ile su ortamındaki çözünmüş oksijenin dengede olduğu konsantrasyondur. Başka bir ifade ile su ortamında bulunabilecek maksimum çözünmüş oksijen konsantrasyonudur. Doğal su ortamlarında çözünmüş oksijen doygunluk konsantrasyonunu etkileyen parametreler; suyun saflığı, suyun sıcaklığı ve açık hava basıncıdır (su ortamının rakımı) (Günay, 2018).

Gaga Gölü Sulak Alanı, diğer çalışma alanı olan Çambaşı Göleti'ne göre diğer etkenlerin yanı sıra deniz seviyesine yakın mesafede olduğu için su sıcaklığı daha yüksek olmasına rağmen rakım farkından kaynaklı basınç değeri ve havadaki oksijen miktarının bölgede daha fazla olabileceği söylenebilir. Gaga Gölü Sulak Alanı'nın mevsimsel analiz bazında ÇO değeri yıllık ortalamasının (9.1 mg/L O $\mathrm{O}_{2}$ ) Çambaşı Göleti’ne $(6.38 \mathrm{mg} / \mathrm{L} \mathrm{O}$ ) nazaran daha yüksek olduğu gözlemlenmiştir (Tablo 2). Bunda sulak alanın su bitkilerince zengin olması da etkilidir. Göllerde ÇO değişimini yansıtan dağılım haritası Şekil 5a'da verilmiştir.

Tablo 2. Çalışma alanlarında mevsimsel çözünmüş oksijen değişiminin ort., min. ve maks. değerleri

\begin{tabular}{r|cccccc}
$\begin{array}{r}\text { Çözünmüş } \\
\text { Oksijen [mg/L] }\end{array}$ & $\begin{array}{c}\text { GAGA GÖLÜ } \\
\text { SULAK ALANI } \\
\text { (rakım: 68 m) }\end{array}$ & En Yüksek & En Düşük & $\begin{array}{c}\text { ÇMBAŞI } \\
\text { GÖLETI (rakım: } \\
1732 \text { m) }\end{array}$ & En Yüksek & En Düşük \\
\hline Illkbahar & $9.40(\% 99)$ & 11.8 & 6.1 & $7.2(\% 69)$ & 7.7 & 6.6 \\
Yaz & $9.23(\% 116)$ & 10.6 & 8.1 & $5.9(\% 73)$ & 6.3 & 5.6 \\
Sonbahar & $10.20(\% 115)$ & 11.3 & 8.3 & $6.1(\% 72)$ & 6.3 & 5.8
\end{tabular}

Gaga Gölü Sulak Alanı'nın oksijen doygunluk değerinin Çambaşı Göleti'nin oksijen doygunluk değerinden yüksek olduğu mevsimsel analiz sonuçlarının ortalamasındaki farktan görülmektedir (Tablo 2). 

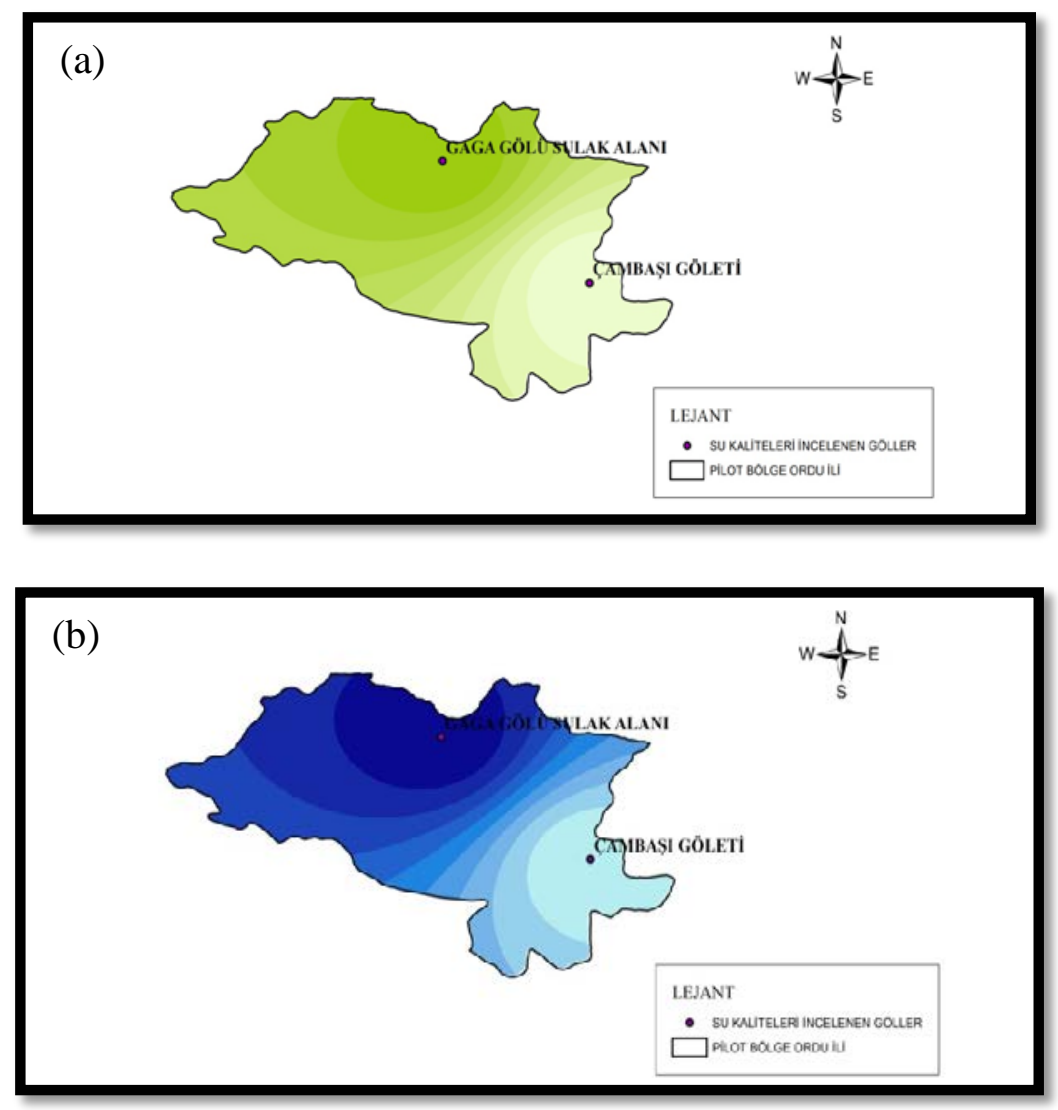

Şekil. 5. Göllerde (a) çözünmüş oksijen (b) doygunluk değişiminin mekansal analizi (yıllık ortalama olarak)

Çambaşı Göleti deniz seviyesine olan yüksekliğinden kaynaklı sıcaklığın az olduğu bir bölgede bulunmasından dolayı ÇO değerinin Gaga Gölü Sulak Alanı'na kıyasla daha yüksek olması gerekirken, bölgenin deniz seviyesine yakın diğer bölgeye kıyasla havanın oksijen miktarının az olması ve basıncın düşük değerde olmasından dolayı ÇO değerinin düşük olduğu gözlemlenmiştir. $\mathrm{Bu}$ nedenler dışında çevresel diğer faktörlerin de bulunduğu göz ardı edilmemelidir.

Gaga Gölü Sulak Alanı'ndaki oksijen doygunluk değerinin yüksek olmasının nedenlerinden biri, deniz seviyesine olan yüksekliğinin diğer çalışma alanına kıyasla yakın olması nedeniyle bu bölgedeki atmosferik basıncın yüksek olması gazların çözünürlüğünü arttırdığı için oksijen doygunluğunun da artığı görülmektedir (Şekil 5b).

Deniz seviyesine yakın olan bölgedeki sulak alanın, uzak olan bölgedeki gölete kıyasla oksijen doygunluğunun fazla olmasının diğer bir nedeni de güneş 1şığının yüksek rakımlı yerlerde yoğun bir şekilde gelmesi sonucu su bitkilerinin daha fazla fotosentez olayı gerçekleştirmesi ve bununla beraber solunum olayının da artması anlamına gelmektedir. Ayrıca diğer fiziksel ve kimyasal parametrelerin veya çevresel etkilerin göz ardı edilmemesi gerekmektedir.

Sığ sularda alglerin aşırı gelişmesi ya da diğer su bitkileri fotosentez yoluyla oksijen üreterek çözünmüş oksijenin doygunluğunun üzerine çıkması sonucu su ortamı aşırı doygun hale gelebilir. 
Diğer taraftan, bitkiler solunum yoluyla oksijen harcadıklarında atmosferden kazanılan oksijenden daha fazlası tüketilir ve çözünmüş oksijen eksikliği ortaya çıkar (Günay, 2018).

\subsection{3. pH Değeri}

Yer üstü su kaynaklarının kimyasal parametrelerinden biri de pH'dır. Bu parametre suyun asitlik veya bazlık derecesini ifade ettiğinden sucul ekosistemdeki canlıların yaşamlarını sürdürmesi açısından önemli bir rol oynamaktadır. Göl ve sulak alanlardaki pH değerini doğrudan veya dolaylı olarak etkileyen çok sayıda değişken bulunmaktadır. Bu değişkenler; jeolojik yapı (gölde), tuzluluk, biyolojik faaliyetler, atmosferik $\mathrm{CO}_{2}$, asit yağmuru, fosil yakıtların yanmasıdır. Düşük pH özellikle ağır metallerin toksik etkilerini de önemli ölçüde etkiler; cıva ve alüminyum gibi ağır metaller toprağın asidifikasyonu sonucu çözünürler ve sucul ekosisteme taşınırlar. Göl suyu içinde pH'ın düşmesi alüminyum gibi ağır metallerin sedimandaki çözünürlüğünü arttırır. Yaz aylarında gözlenen yüksek fotosentez oranı suda pH'ın yükselmesine neden olur. Yaz aylarındaki aşırı buharlaşma nedeniyle de pH 12'ye kadar çıkabilir (alkali madde birikmesiyle). Göllerdeki veya sulak alanlardaki mevsimsel değişimler, bitki örtüsü, deniz seviyesine olan yükseklikten kaynaklı basınç dalgalanması ve atmosferde bulunan gazların çökelmesi gibi olayların dolaylı olarak pH değerini etkilediği bilinmektedir (Güner, 2011).

Atmosferik çökelmenin su ortamı ve canlılara etkileri de oldukça önemlidir. Yüzeysel suya atmosferik çökelme yoluyla giren kirleticiler genelde partiküllerin yüzeyine tutunurlar veya çözünerek suda kalırlar. Ayrıca, atmosferik çökelmeyle tatlı su göllerinde asidite artmakta, bunun neticesi canlı türlerinde azalmalar ve yok olmalar gözlenmektedir (Bayraktar ve Turalığlu, 2004). Deniz seviyesine olan yükseklik arttıkça açık hava basıncındaki azalma nedeniyle sudaki gazların çözünürlüğünün azalması, yükseklere çıkıldıkça sıcaklığın değişim göstermesi ve bitki örtüsünün değişim göstererek karbondioksitin tutulma miktarındaki değişimler $\mathrm{pH}$ değerini etkilemektedir. Bu etkilerin araştırma alanları olan Gaga Gölü Sulak Alanı ve Çambaşı Göleti'nin pH değeri analiz sonuçlarının mevsimsel ortalama değerlerinde de birbirinden farklılık gösterdiği görülmektedir (Tablo 3). Göllerdeki pH değişimi mekânsal analizi Şekil 6’da haritalandırılmıştır.

Tablo 3. Çalışma alanlarında mevsimsel pH değişiminin ort., min. ve maks. değerleri

\begin{tabular}{|c|c|c|c|c|c|c|}
\hline$p H$ & $\begin{array}{c}\text { GAGA GÖLÜ } \\
\text { SULAK ALANI } \\
\text { (rakım: } 68 \mathrm{~m})\end{array}$ & En Yüksek & En Düşük & $\begin{array}{c}\text { ÇAMBSŞ } \\
\text { GÖLETI (rakım: } \\
1732 \mathrm{~m})\end{array}$ & En Yüksek & En Düşük \\
\hline İlkbahar & 7.9 & 8.0 & 7.6 & 6.8 & 6.9 & 6.6 \\
\hline Yaz & 8.5 & 9.0 & 7.7 & 6.8 & 7.0 & 6.7 \\
\hline Sonbahar & 7.8 & 8.7 & 7.3 & 6.7 & 6.8 & 6.7 \\
\hline
\end{tabular}




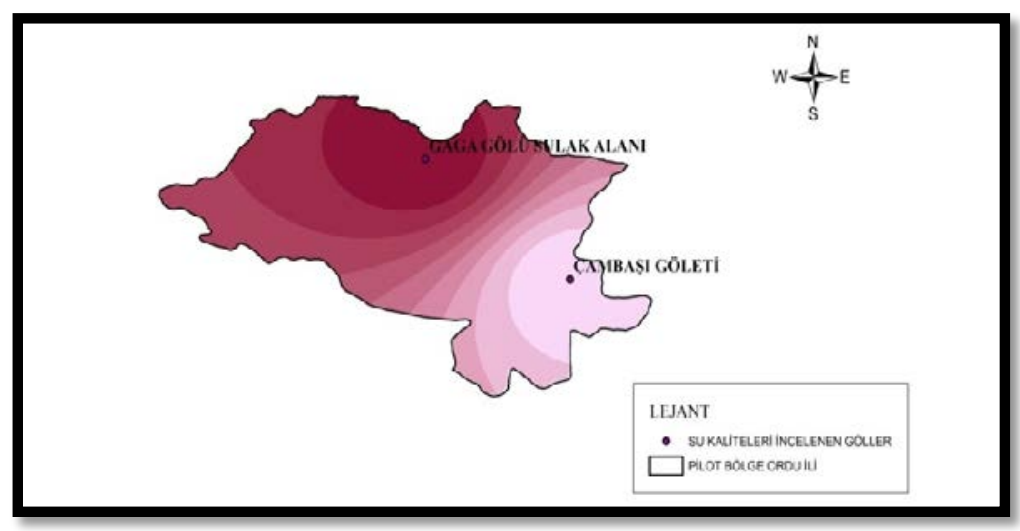

Şekil 6. Göllerde $\mathrm{pH}$ değişiminin mekansal analizi (yıllık ortalama olarak)

\subsection{4. İletkenlik ve Toplam Çözünmüş Katı Madde (TÇM) Miktarı}

Göllerde veya sulak alanlarda iletkenlik; yağışlar sonucu oluşan yüzeysel akışlardan, bağlantılı olan su kollarının geçtiği alanlardan taşımış olduğu alüvyonlardan, sucul ortam içerisinde dış etkenlerden kaynaklı oluşmuş çözeltilerden gelen iyonlardan oluşur. İletkenlik değerini etkileyen faktörler; sıcaklık, iyon konsantrasyonu, tuzluluk vb. olarak sıralanabilir, ancak bu faktörler üzerinde dolaylı yoldan etki ederek iletkenliği de etkileyebilecek nedenler bulunmaktadır. Yükseklik arttıkça sıcaklığın azalması, dolayısıyla buharlaşmanın azalması, su içerisindeki hem tuzluluk miktarının hem de iyon konsantrasyonunun seyreltik kalması, aynı zamanda yüksek bölgelerde basıncın azalması gazların çözünürlüğünü de etkilemektedir. Tüm bu nedenlerden dolayı deniz seviyesine olan yükseklik faktörü de iletkenlik değerini dolaylı olarak etkileyen bir faktördür.

Denizden 68 m yükseklikte yer alan Gaga Gölü Sulak Alanı iletkenlik değerinin, 1732 m rakıma sahip Çambaşı Göleti iletkenlik değerinden oldukça yüksek olduğu görülmektedir (Tablo 4). Aradaki bu fark deniz seviyesine olan yüksekliğin dolaylı yoldan (deniz üstü atmosferik etkilerin denize daha yakın olan göl yüzeyine daha fazla nüfuz etmesi) iletkenlik değerini etkilemiş olduğunun bir göstergesidir. Çambaşı Göleti suyunun Gaga Gölü Sulak Alanı suyuna göre daha az iyon içeriğine sahip bir su olduğunu gösterir mekânsal analiz Şekil 7’de verilmiştir.

Tablo 4. Çalışma alanlarında mevsimsel iletkenlik değişiminin ort., min. ve maks. değerleri

\begin{tabular}{r|cccccc}
$\begin{array}{r}\text { Illetkenlik } \\
(\mu S / \mathrm{cm})\end{array}$ & $\begin{array}{c}\text { GAGA GÖLÜ } \\
\text { SULAK ALANI } \\
\text { (rakım: } 68 \mathrm{~m})\end{array}$ & En Yüksek & En Düşük & $\begin{array}{c}\text { CAMBAŞI } \\
\text { GÖLETI (rakım: } \\
1732 \mathrm{~m})\end{array}$ & En Yüksek & En Düşük \\
\hline Ilkbahar & 483 & 552 & 397 & 33 & 36 & 30 \\
Yaz & 296 & 434 & 190 & 34 & 35 & 30 \\
Sonbahar & 429 & 521 & 253 & 33 & 35 & 32
\end{tabular}




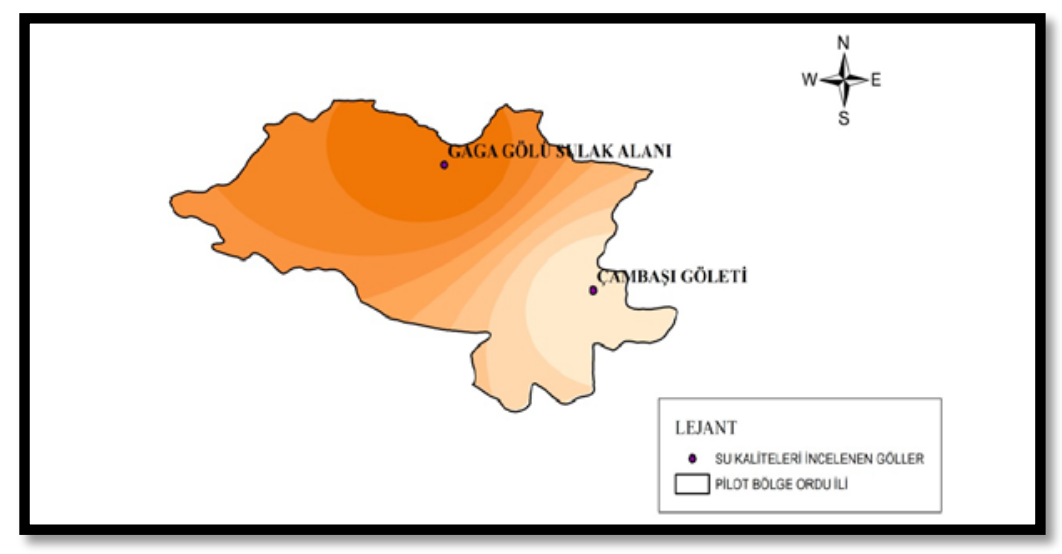

Şekil 7. Göllerde iletkenlik değişiminin mekansal analizi (yıllık ortalama olarak)

Suyun tadını etkileyen en önemli etken, sudaki çözünmüş maddelerdir. Örneğin tuz, kireç, demir, alüminyum vs. suda çözünen maddelerdir. Sudaki çözünmüş maddeler ne kadar çok ise suyun kendi doğal tadı o kadar bozulur. Jeolojik yapıya, sıcaklık ve yağış miktarına bağlı olarak değişen suyun elektriksel iletkenliği aynı zamanda sudaki toplam çözünmüş madde miktarının da bir göstergesidir (Taş, 2006; Taş ve Kolören, 2017). Tabiatta sular, kaynaklarına göre, TÇM değerleri açısından farklılıklar gösterir. $1500 \mathrm{mg} / \mathrm{L}$ TÇM değeri "Tatlı Su” kaynakları için üst limittir. 1000 5000 mg/L TÇM'ye sahip sular genel olarak “Acı Su” olarak tabir edilirken, 5000 15 000 mg/L TÇM’ye sahip sular “Çok Acı Su” ve daha yüksek konsantrasyonlarda TÇM içeren sular, "Tuzlu Su” olarak tanımlanır (Royal, 2016). Gaga Gölü Sulak Alanı ve Çambaşı Göleti kimyasal su kalite parametrelerinden biri olan TÇM değeri, iletkenlik değerinde olduğu gibi çözünmüş maddelerden kaynaklı bir değerdir. Bu nedenle iletkenlik değerini doğrudan veya dolaylı olarak etkileyen faktörler büyük ölçüde TÇM değerini de etkilemektedir. İki sucul ortam arasındaki farkın mevsimsel analiz sonuçlarının istatistiki ortalamaları ve rakıma bağlı olarak mekânsal analizleri Tablo 5 ve Şekil 8'de gösterilmiştir.

Tablo 5. Çalışma alanlarında mevsimsel TÇM değişiminin ort., min. ve maks. değerleri

\begin{tabular}{r|cccccc} 
TÇM $(\mathrm{mg} / \mathrm{L})$ & $\begin{array}{c}\text { GAGA GÖLÜ } \\
\text { SULAK ALANI } \\
\text { (rakım: } 68 \mathrm{~m})\end{array}$ & En Yüksek & En Düşük & $\begin{array}{c}\text { ÇAMBAŞI GÖLETİ } \\
\text { (rakım: } 1732 \text { m) }\end{array}$ & $\begin{array}{c}\text { En } \\
\text { Yüksek }\end{array}$ & $\begin{array}{c}\text { En Düşük } \\
\text { Ilkbahar }\end{array}$ \\
Yaz & 242 & 277 & 200 & 16 & 18 & 14 \\
\hline Sonbahar & 148 & 217 & 95 & 17 & 18 & 15 \\
& 214 & 260 & 126 & 17 & 17 & 16
\end{tabular}




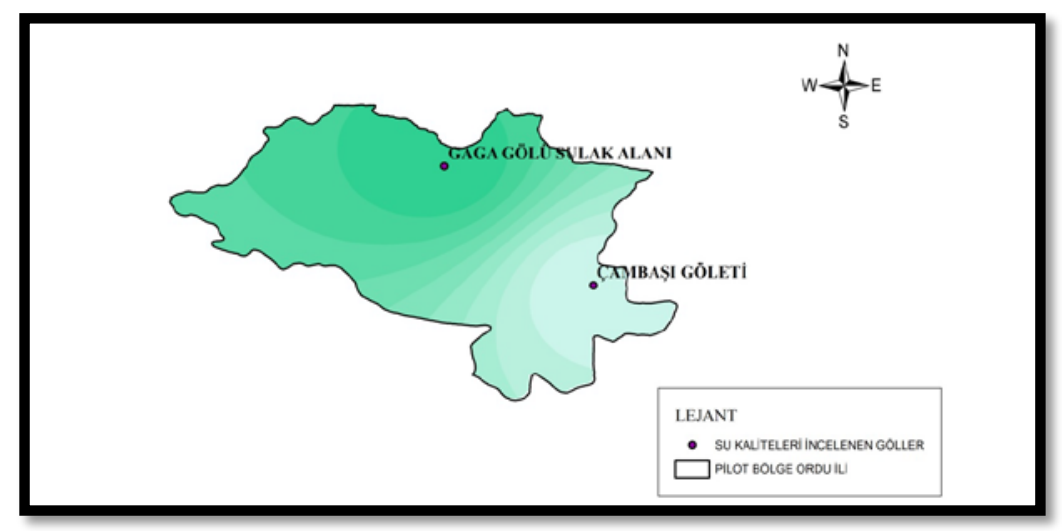

Şekil 8. Göllerde TÇM değişiminin mekansal analizi (yıllık ortalama olarak)

Gaga Gölü Sulak Alanı'nın TÇM miktarının Çambaşı Göleti'ne göre daha fazla olmasında, su yollarıyla bağlı bulunduğu Gaga Gölü'nün oluşum şekli ve çevresindeki tarım arazilerinden karışan atıklar başlıca unsurlardır. Göl, heyelan enkazının oluşturduğu çukurluğun sularla dolması sonucunda oluşmuştur. Oluşum şekliyle Gaga Gölü, Karadeniz Bölgesi’nde örnekleri görülen tipik heyelan setti göllerinden farklıdır (Akkan ve Gürgen, 1993; Taş, 2012).

\subsubsection{Amonyum-Azotu, Nitrit-Azotu ve Nitrat-Azotu Değerleri}

Azot su ekosistemi için önemli bir kimyasal parametre olup aynı zamanda sınırlayıcı bir besin maddesi olarak kabul edilir. Azot canlıların yaşamları içerisinde bulunduğundan canlılardan doğaya karışan organik maddelerin de yapısında bulunmaktadır. Azot atmosfer içerisinde gerçekleşen olaylarda, canlı kalıntılarından doğal olarak su ekosistemine karışabildiği gibi suni işlemler sonucu yani inorganik gübreleme sonucu da yağışlar ve yüzeysel akışlar nedeniyle su ekosistemine karışmaktadır. Dünya genelinde, azot ve fosforun aşırı şekilde girişiyle meydana gelen göl ötrofikasyonu, su kalitesinin kötüleşmesine ve biyoçeşitliliğin önemli ölçüde azalmasına neden olmaktadır (Kristensen ve Hansen, 1994; Dodson ve ark., 2000). Azotlu bileşikler suyun kalitesi hakkında bilgi verebilen parametrelerdendir (Taş ve Kolören, 2017).

Doğada gerçekleşen azot döngüsünde oksitleyici olarak oksijen kullanıldığından bu durum su ekosisteminde oksijen eksikliği de yaratmaktadır. Nitrifikasyon bakterilerinin etkinliği sıcaklık ile doğru orantılı olmasından dolayı deniz seviyesinden yükseklere çıkıldıkça azalan sıcaklık, nitrifikasyon bakterilerinin etkinliğini azaltma yönünde etki edebileceği gibi azot ve türevlerinin miktarlarını da etkileyebilecektir. Ancak araştırma alanları arasındaki rakım kaynaklı sıcaklık değişimleri ve sonucundaki amonyum, nitrit ve nitrat değerlerindeki farlılıkların çok belirgin olmadığı görülmektedir (Tablo 6). Bunun nedeni olarak, hem Gaga Gölü Sulak Alanı hem de Çambaşı Göleti için bu değerler arasındaki farkı dengeleyebilecek ortam koşullarının etkin olması 
gösterilebilir. Rakıma bağlı olarak her iki göldeki azot kaynaklı kirliliğin mekânsal analizleri Şekil 9(a), (b) ve (c)'de gösterilmiştir.

Tablo 6. Çalışma alanlarında mevsimsel amonyum, nitrit ve nitrat azotu değişimininin ort., min. ve maks. değerleri

\begin{tabular}{|c|c|c|c|c|c|c|}
\hline Parametre & $\begin{array}{c}\text { GAGA GÖLÜ } \\
\text { SULAK ALANI } \\
\text { (rakım: } 68 \mathrm{~m})\end{array}$ & En Yüksek & En Düşük & $\begin{array}{c}C ̧ A M B A S S I \\
G \ddot{O L E T I} \\
\text { (rakım: } 1732 \mathrm{~m})\end{array}$ & En Yüksek & En Düşük \\
\hline \multicolumn{7}{|l|}{$\begin{array}{r}\text { Amonyum Azotu } \\
(\mathrm{mg} / \mathrm{L} \mathrm{NH}-\mathrm{N})\end{array}$} \\
\hline Ilkbahar & 0.07 & 0.12 & 0.01 & 0.10 & 0.11 & 0.09 \\
\hline$Y a z$ & 0.38 & 0.62 & 0.11 & 0.73 & 1.15 & 0.14 \\
\hline Sonbahar & 0.65 & 0.67 & 0.62 & 1.31 & 1.35 & 1.27 \\
\hline $\begin{array}{r}\text { Nitrit Azotu } \\
\left(\mathrm{mg} / \mathrm{L} \mathrm{NO} \mathrm{N}_{2}-\mathrm{N}\right)\end{array}$ & & & & & & \\
\hline Ilkbahar & 0.013 & 0.02 & 0.001 & 0.003 & 0.004 & 0.002 \\
\hline$Y a z$ & 0.013 & 0.02 & 0.001 & 0.009 & 0.013 & 0.002 \\
\hline Sonbahar & 0.213 & 0.32 & 0.03 & 0.016 & 0.018 & 0.014 \\
\hline $\begin{array}{r}\text { Nitrat Azotu } \\
(\mathrm{mg} / \mathrm{L} \mathrm{NO}-\mathrm{N})\end{array}$ & & & & & & \\
\hline Ilkbahar & 0.70 & 1.1 & 0.2 & 0.40 & 0.5 & 0.3 \\
\hline Yaz & 0.17 & 0.2 & 0.1 & 0.93 & 1.3 & 0.3 \\
\hline Sonbahar & 0.30 & 0.3 & 0.3 & 1.50 & 1.7 & 1.3 \\
\hline
\end{tabular}



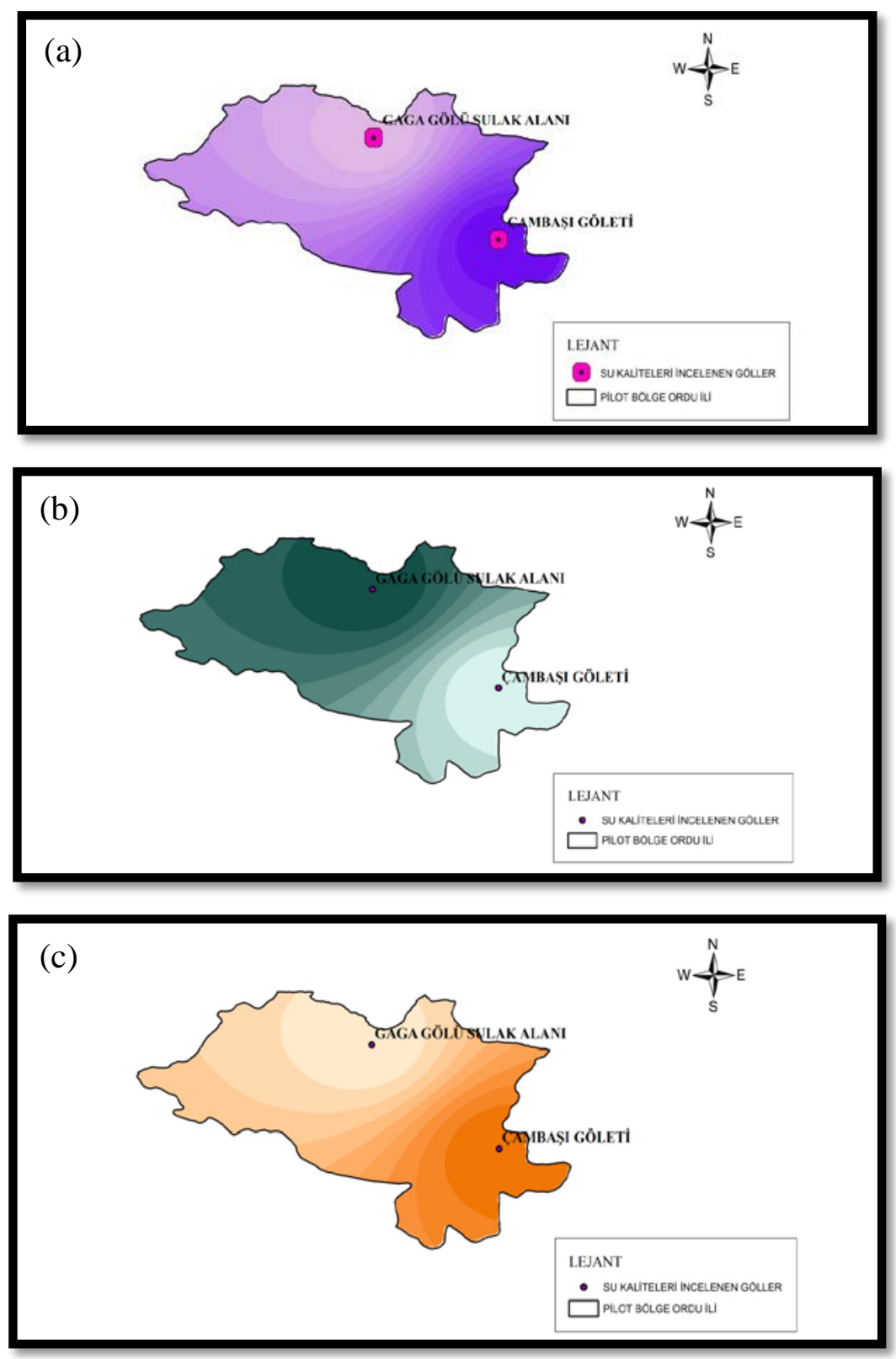

Şekil 9. Göllerde (a) amonyum, (b) nitrit ve (c) nitrat azotu değişiminin mekânsal analizi

\subsubsection{Orto ve Toplam Fosfor Değerleri}

Fosfat göllerde ve sulak alanlar gibi durgun sularda azotla birlikte ötrofikasyona neden olan en temel besin tuzudur. Ancak, fosfat anahtar bir rol oynar, fazla olması durumunda algler ve makrofitler hızla çoğalmaya başlar. Fosfat; azot ve türevleri gibi doğal süreçlerle su ortamına karışabileceği gibi inorganik gübreler vb. yapay yollar ile de sucul ekosistemlere aşırı miktarlarda giriş yapabilir. Göllerde nütrientlerin birikmesi de su kalitesi için ciddi bir tehdit olarak görülmektedir (Beklioğlu ve ark., 2003). Kirlenmemiş doğal sularda oldukça düşük konsantrasyonlarda bulunan fosfat ortamın verimliliği hakkında bilgi verir (Tepe ve Boyd, 2003). 
Gaga Gölü Sulak Alanı ve Çambaşı Göleti kimyasal su kalitesi parametreleri olan fosfat değerlerinin mevsimsel analiz sonuçlarının karşılaştırılması yapıldığında, genel anlamda sonbahar döneminde her iki araştırma alanı için de artış gösterdiği, en yüksek değerlerin ise yaz mevsiminde ortaya çıktığı görülmektedir (Tablo 7). Özellikle deniz seviyesinde yer alan göllerde azot ve fosfor konsantrasyonlarının değişiminde mevsimlerin istatistiki olarak anlamlı bir fark oluşturduğu ve yaz mevsiminde organik karbon içeriğindeki artışa paralel olarak nütrient seviyelerinin de arttığ yapılan çalışmalarda da açıkça gözlemlenmiştir (Cüce ve Bakan, 2017a ve 2017b). Bunun nedeni sonbahar döneminde bölgenin fazla miktarda yağış alarak bitkisel, hayvansal atıkların veya kalıntıların çürümesine elverişli bir ortamın oluşmasıdır. Ayrıca Gaga Gölü Sulak Alanı'nın fosfat değerlerinin Çambaşı Göleti fosfat değerlerinden yüksek olmasının sebebi, gölete göre nispeten çok küçük yüzey alanı ve sığ olmasına rağmen sulak alanı çevreleyen bölgeden nütrient akışına izin veren kaynakların (fındık bahçelerinin bulunması) olmasıdır (Şekil 10(a) ve (b)).

Tablo 7. Çalışma alanlarında mevsimsel orto-fosfat ve toplam fosfor değişiminin ort., min. ve maks. değerleri

\begin{tabular}{|c|c|c|c|c|c|c|}
\hline Parametre & $\begin{array}{c}\text { GAGA GÖLÜ } \\
\text { SULAK ALANI } \\
(\text { rakım: } 68 \mathrm{~m})\end{array}$ & En Yüksek & En Düşük & $\begin{array}{c}C ̧ A M B A S ̧ I \\
G \ddot{O} L E T \dot{I} \\
\text { (rakım: } 1732 \mathrm{~m})\end{array}$ & En Yüksek & En Düşük \\
\hline \multicolumn{7}{|l|}{$\begin{array}{r}\text { Orto-Fosfat } \\
\left(\mathrm{mg} / \mathrm{L} \mathrm{PO} \mathrm{PO}_{4}-\mathrm{P}\right)\end{array}$} \\
\hline Ilkbahar & 0.44 & 0.54 & 0.34 & 0.32 & 0.33 & 0.30 \\
\hline Yaz & 0.49 & 0.56 & 0.37 & 0.37 & 0.48 & 0.19 \\
\hline Sonbahar & 0.53 & 0.54 & 0.52 & 0.51 & 0.52 & 0.49 \\
\hline $\begin{array}{r}\text { Toplam Fosfor } \\
(\mathrm{mg} / \mathrm{L} P)\end{array}$ & & & & & & \\
\hline Ilkbahar & 1.41 & 1.63 & 1.05 & 1.00 & 1.02 & 0.98 \\
\hline$Y a z$ & 1.50 & 1.75 & 1.13 & 1.32 & 1.35 & 1.29 \\
\hline Sonbahar & 1.63 & 1.65 & 1.61 & 1.43 & 1.49 & 1.38 \\
\hline
\end{tabular}



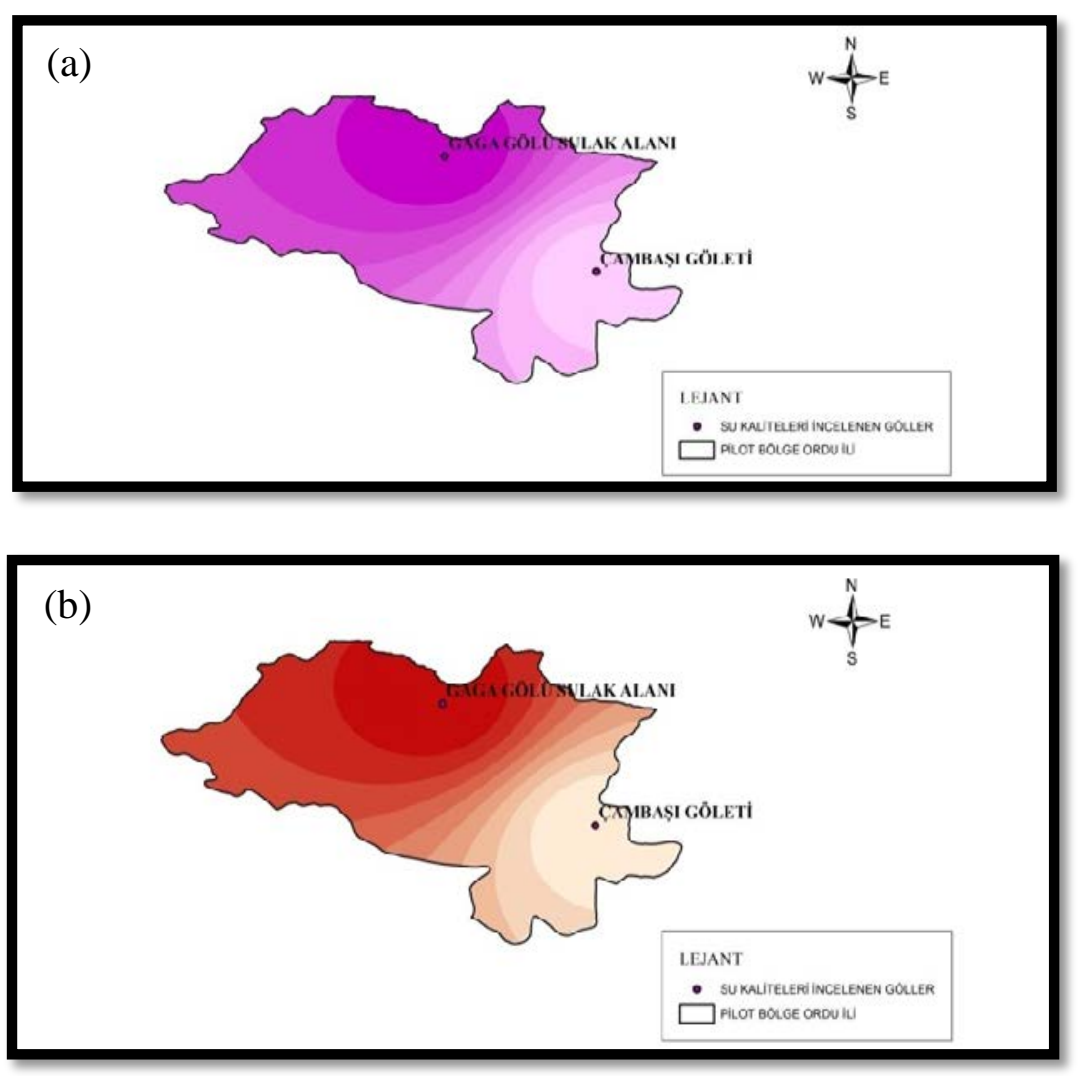

Şekil 10. Göllerde (a) orto-fosfat ve (b) toplam-fosfat değişiminin mekânsal analizi (yıllık ortalama olarak)

\subsubsection{Kalsiyum, Magnezyum ve Toplam Sertlik (CaCO3) Değeri}

Kalsiyum ve bileşikleri suya sertlik özelliği veren en önemli iyonlardan olduğundan çok değişik konsantrasyonlarda sucul sistemlerde bulunabilirler. Genellikle sudaki kalsiyum iyonu kaynağını karbonatlı ve sülfatlı kalsiyum mineralleri teşkil eder (Taş, 2011). Bitkiler topraktan aldıkları mineralleri belirli kısımlarında depo ederler, ancak yaprak kısmında biriken kalsiyumun bitkinin mevsimsel yaprak dökümü zamanında tekrar toprağa dönmesi toprağın mevsimsel olarak kalsiyum miktarının artmasına olanak sağlamaktadır. Gaga Gölü Sulak Alanı çevresinde bulunan fındık tarım arazilerinin, kışın yaşanabilecek don olaylarına veya gelişim zamanındaki topraktaki haşerelere karşı korunabilmesi için bahçelere atılan kireç, topră̆ın kalsiyum minerali açısından zenginleşmesine ve yüzeysel akışlar ile yıkanarak sulak alana karışmasıyla da suyun sertlik derecesinin artmasına yol açmaktadır. Çambaşı Göleti yakın çevresinde fındık tarım arazisinin bulunmaması mevsimsel değişimlere göre sertlik değerinin Gaga Gölü Sulak Alanı'na kıyasla daha düşük değerlerde olmasının nedenleri arasında yer almaktadır (Tablo 8). 
Tablo 8. Çalışma alanlarında mevsimsel toplam sertlik değişiminin ort., min. ve maks. Değerleri

\begin{tabular}{|c|c|c|c|c|c|c|}
\hline Parametre & $\begin{array}{c}\text { GAGA GÖLÜ } \\
\text { SULAK ALANI } \\
\text { (rakım: } 68 \mathrm{~m})\end{array}$ & En Yüksek & En Düşük & $\begin{array}{c}C ̧ A M B A S ̧ I \\
G \ddot{O L E T I} \\
\text { (rakım:1732 m) }\end{array}$ & En Yüksek & En Düşük \\
\hline \multicolumn{7}{|l|}{$\begin{array}{r}\text { Kalsiyum } \\
\left(m g / L \mathrm{Ca}^{+2}\right)\end{array}$} \\
\hline İlkbahar & 80.74 & 98.88 & 64.68 & & 0.33 & 0.30 \\
\hline Yaz & 55.08 & 85.65 & 34.34 & 0.37 & 0.48 & 0.19 \\
\hline Sonbahar & 85.26 & 95.52 & 68.73 & 0.51 & 0.52 & 0.49 \\
\hline \multicolumn{7}{|l|}{$\begin{array}{l}\text { Magnezyum } \\
\left(\mathrm{mg} / \mathrm{L} \mathrm{Mg}{ }^{+2}\right)\end{array}$} \\
\hline Ilkbahar & 7.06 & 10.76 & 3.25 & 0.73 & 0.75 & 0.68 \\
\hline$Y a z$ & 7.52 & 9.53 & 6.18 & 1.13 & 1.32 & 0.77 \\
\hline Sonbahar & 6.03 & 10.21 & 3.56 & 1.39 & 1.41 & 1.39 \\
\hline $\begin{array}{r}\text { T. Sertlik } \\
\left(\mathrm{mg} / \mathrm{L} \mathrm{CaCO}_{3}\right)\end{array}$ & & & & & & \\
\hline Ilkbahar & 260 & 315 & 206 & 9 & 8 & 9 \\
\hline$Y a z$ & 215 & 382 & 111 & 14 & 12 & 16 \\
\hline Sonbahar & 237 & 251 & 218 & 16 & 15 & 16 \\
\hline
\end{tabular}

Gaga Gölü Sulak Alanı'nın ve Çambaşı Göleti'nin kimyasal su kalitesi parametrelerinden toplam sertlik miktarını incelerken değindiğimiz gibi magnezyum ve kalsiyum sularda sertliğe neden olurlar. Göllerde magnezyum oranının düşük olması gölün fitoplankton verimliliğini önemli ölçüde etkiler, bunun sonucunda göl oligotrofik özellik kazanır (Egemen, 2006). Ayrıca toplam çözünmüş madde miktarını da etkilemektedir. $\mathrm{Bu}$ değerlerin araştırma alanlarına göre karşılaştırmasını yaptığımızda, toplam sertlikteki mevsimsel analiz sonuçlarına göre oluşan fark kalsiyum ve magnezyum değerlerinde de gözlemlenmiştir (Tablo 8). Dağlardan gelen sular sert değildir, bu bölgelerde yeraltı suları derinlikleri yüzeye yakındır. Yağmur suları da yüksek kesimlerde çok fazla kayaçla karşılaşmaz, böylece az miktarda taş çözer ve yerüstü sularına karışır. Kireç problemiyle fazla karşılaşılmaz (Kırımker, 2014). Bu nedenlerden dolayı deniz seviyesinden yüksekliğe bağlı olarak, araştırma alanlarındaki su kalite değerlerinden toplam sertlik değerinin fark edilir düzeylerde olduğu mekânsal analiz sonucundan da görülmektedir (Şekil 11(a), (b) ve (c)). 

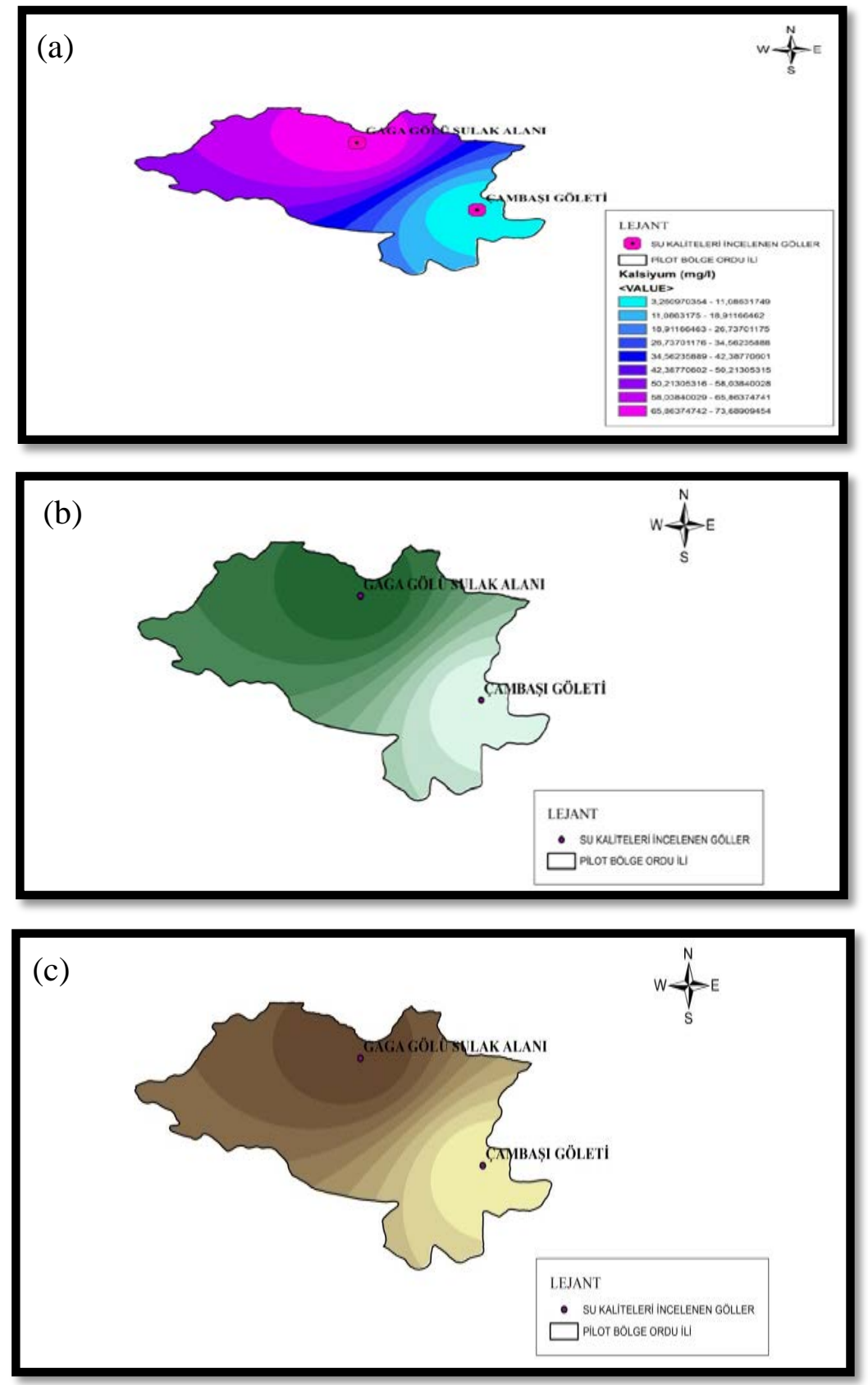

Şekil 11. Göllerde (a) kalsiyum, (b) magnezyum ve (c) toplam sertlik değişiminin mekânsal analizi

\subsubsection{Klorofil-a Değeri}

Tüm pigmentli alglerde bulunan klorofil-a yüzey suyundaki planktonik alg biyoması hakkında bilgi verir. Sucul ekosistemde biyolojik bir gösterge olarak klorofil-a pigmenti aynı zamanda suyun prodüktivitesini ve verimliliğini de gösterir (Taş ve ark., 2019). Gaga Gölü Sulak Alanı'nın klorofil- $a$ değerinin Çambaşı Göleti'ne kıyasla her dönem oldukça yüksek olduğu tespit edilmiştir. Bunun temel nedeni olarak her iki gölün morfolojik yapısının farklı olması ve meteorolojik olarak farklı etkenlere maruz kalmaları gösterilebilir. Sulak alanın doğal oluşumlarla meydana gelmesi nedeniyle dip kısmı tamamen yerel toprak yüzeyle etkileşim halindedir ve bentik 
tabakanın daha yaşlı olması sebebiyle oksijen ihtiyacı ve nütrient salım hızları yüksektir. Sulak alanlar genel olarak yüksek oranda fotosentetik aktiviteye sahiptir. Göletler ise kaplama malzemeleriyle (jeomembran) yapay olarak oluşturulmalarından dolayı sudaki fotosentetik aktiviteler kısıtlı seviyede gelişim gösterir. Araştırma yapılan gölete bağlı irili ufaklı derelerin getirmiş olduğu alüvyonlar ve rüzgâr vb. etkenlerden dolayı gölet içerisine taşınarak birikmiş organik kökenli diğer tortulardan kaynaklanan bu tür aktivitelerde artış gözlenebilmektedir. Yüzey alanı sulak alana göre oldukça büyük olan yapay göletin ötrofik açıdan daha iyi kalitede olmasında rakım yüksekliğine bağlı iklim koşulları da etkendir. Keza, yüksek bölgelere çıkıldıkça noktasal kirlenme kaynaklarından mümkün olduğunca uzaklaşılmakta ve oksijen doygunluğu açısından önemli olan sıcaklık değerleri gibi bazı fiziko-kimyasal faktörler de değişmektedir. Bu nedenle iki araştırma alanı arasında dönemsel olarak fotosentetik aktivite farkı oluşmaktadır (Tablo 9 ve Şekil 12). Bununla birlikte diğer etkenlerin de (sıcaklık, çözünmüş oksijen, karbondioksit, 1şık, derinlik, sucul flora vb.) göz ardı edilmemesi gerekir.

Tablo 9. Çalışma alanlarında mevsimsel klorofil-a değişiminin ort., min. ve maks. değerleri

\begin{tabular}{r|cccccc}
$\begin{array}{r}\text { Klorofil-a } \\
{[\mu \mathrm{g} / \mathrm{L}]}\end{array}$ & $\begin{array}{c}\text { GAGA GÖLÜ } \\
\text { SULAK ALANI } \\
\text { (rakım: 68 m) }\end{array}$ & En Yüksek & En Düşük & $\begin{array}{c}\text { ÇAMBAŞI } \\
\text { GÖLETİ } \\
\text { (rakım:1732 m) }\end{array}$ & En Yüksek & En Düşük \\
\hline $\begin{array}{r}\text { Ilkbahar } \\
\text { Yaz }\end{array}$ & 1.48 & 2.52 & 0.93 & 0.15 & 0.18 & 0.12 \\
Sonbahar & 44.98 & 67.2 & 26.43 & 0.47 & 0.65 & 0.38 \\
& 50.06 & 118.29 & 15.93 & 0.35 & 0.39 & 0.31
\end{tabular}

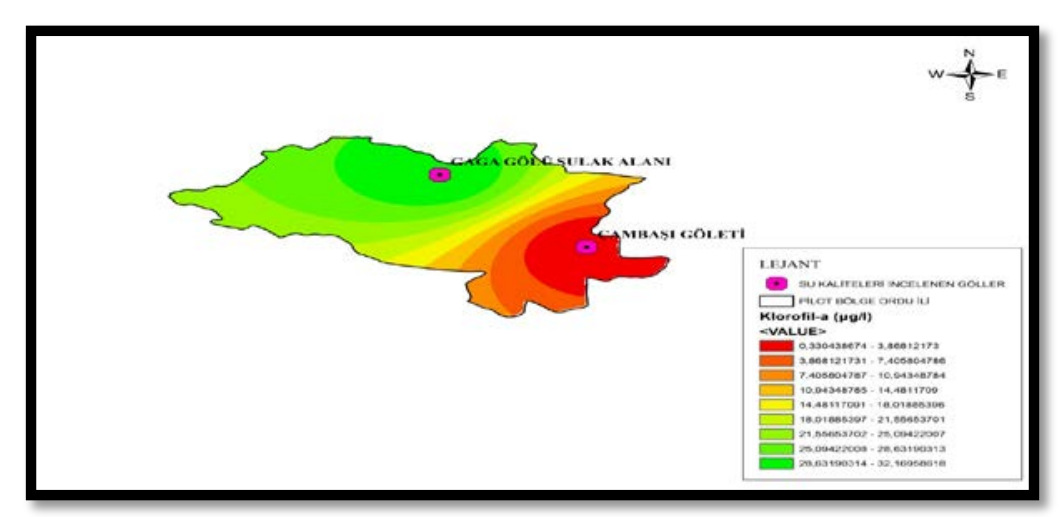

Şekil 12. Göllerde klorofil-a değişiminin mekânsal analizi (yıllık ortalama olarak)

Yerüstü Su Kalitesi Yönetmeliği (2012) EK-5 Çevresel kalite standartları uyarınca ve her iki gölün ötrofikasyon kriterlerine göre su kalite sınıfları, bu çalışmada elde edilen kimyasal parametreler bazında (ekolojik kriterler hariç) değerlendirilmiştir. Buna göre; yıllık ortalama çözünmüş oksijen açısından Gaga Gölü Sulak Alanı I. Sınıf, Çambaşı Göleti II. Sınıf iken, yıllık ortalama iletkenlik ve pH değerleri açısından her iki gölün de I. Sınıf ya da yakın özellikte, özellikle 
azot içerikleri arasında yıllık ortalama amonyum azotu dikkate alındığında her iki yerüstü su kaynağının da II. Sınıf kalitede olduğu görülmüştür. Bununla birlikte, fosfor içerikleri dikkate alındığında, orto-fosfat değerlerinin yaklaşık olarak her mevsim iki gölde III. Sınıf su kalitesi sergilediği fakat toplam fosfor ölçümlerinin IV. Sınıf kalite yüzey suyuna sahip su özelliği gösterdiği tespit edilmiştir. Ayrıca aynı yönetmeliğin ötrofikasyon kriterlerine göre (Tablo 9), oksitlenmiş azotlu bileşikler (nitrit ve nitrat azotu) açısından ilkbaharda Gaga Gölü Sulak Alanı, sonbaharda ise Çambaşı Göleti'nin mezotrofik üstü duruma geçtiği söylenebilir. Yıllık ortalama toplam fosforun mevsimsel olarak üç dönemde de aşırı yüksek olması beraberinde her iki su kütlesinin hiperötrofik göl yapısına kısa süreli de olsa geçiş yaptıklarını göstermiştir. Ancak, göl yüzeylerinden alınan klorofil-a ölçüm sonuçlarına göre, Gaga Gölü Sulak Alanı ilkbaharda oligotrofik yapıda iken sonraki dönemlerde (özellikle sonbahar başında $118 \mu \mathrm{g} / \mathrm{L}$ ile pik değer) hiper-ötrofik duruma geçmektedir (çözünmüş oksijen oldukça yüksek olmasına rağmen). Çambaş1 Göleti ise çözünmüş oksijen içeriğine göre her dönem mezotrofik bandın içinde yer alırken sadece klorofil- $a$ parametresi söz konusu olduğunda her üç dönemde de oligotrofik durumunu (> 1 $\mu \mathrm{g} / \mathrm{L})$ korumaktadır.

Çalışma alanlarının su kaliteleri arasındaki farklılığın tek sebebinin yükseklikten ziyade çevresel etkenler ve tarımsal faaliyetlerden kaynaklı olduğu söylenebilir. Deniz seviyesine olan yükseklik klimatik faktörlerin farklı olmasına yol açar. Dolayısıyla iklimsel faktörler, özellikle sıcaklık, sucul ekosistemdeki ekolojik faktörler üzerinde doğrudan ve/veya dolaylı olarak etkili olarak bölgesel bitki florasının çeşitliliğinin artması veya azalması gibi pek çok çevresel şartlarda değişiklikler yaşanmasına yol açmaktadır. Yüksek rakımlı yerlere çıkıldıkça sıcaklık miktarının azalması 1732 m yüksekliğe sahip Çambaşı Göleti'nin de yüzey suyu sıcaklığını etkileyerek $68 \mathrm{~m}$ yüksekliğe sahip Gaga Gölü Sulak Alanı'nın su sıcaklığı değerinin altına düştüğü mevsimsel analiz sonuçlarının değerlendirilmesi sonucunda gözlemlenmiştir. Doğal suların yaşamsal döngülerinin en önemli kaynağı ve parametresi olan çözünmüş oksijen değeri, doğal sularda yaşayan canlıların yaşam kaynağı olmakla beraber göl veya sulak alan gibi durgun ve kirlenmeye müsait suların temizlenmesine yardımcı bir kaynaktır. Çözünmüş oksijen değeri de diğer fiziksel ve kimyasal parametreler gibi çalışma alanlarının deniz seviyesine olan yüksekliğinden etkilenmiştir. Deniz seviyelerinden yüksek bölgelere çıkıldıkça atmosferdeki oksijen seviyesindeki azalma ve yüksek bölgelerde azalan basıncın gazların çözünürlüğüne etki etmesi bu etkilenmenin muhtemel sebebidir. Yine su sıcaklığı da gazların çözünürlüğünü doğrudan etkilemektedir. 


\section{Sonuç ve Öneriler}

Aynı bölgede morfolojik olarak farklı yapıdaki iki yüzey suyu kaynağında üç mevsim konumsal analizler üzerine odaklanmış bu çalışmada, rakımsal farklılığın yüzey suyu kalitesine olan etkileri değerlendirilmiştir. Fiziksel ve kimyasal su parametreleri analiz sonuçlarının genel etkiler altında karşılaştırılması sonucu Gaga Gölü Sulak Alanı'nın sıcaklık, çözünmüş oksijen, pH, iletkenlik, toplam çözünmüş madde miktarı gibi birçok parametresinin Çambaşı Göleti'nden daha yüksek değerlere sahip olduğu görülmüştür. Su kalitesindeki gözlemlenen bu farkın sebeplerinin iki su ekosisteminin bulunduğu bölge arasındaki rakım farkı göz önüne alınarak değerlendirilmesi yapılmış ve birçok parametrenin etkilendiği görülmüştür.

Gaga Gölü ve sulak alanı ile Çambaşı Yaylası ve çevresi rekreasyonel olarak değerlendirilen alanlardır. Gaga Gölü özellikle yaz aylarında, Çambaşı Göleti ise yaz ve kış aylarında oldukça fazla ziyaret edilmektedir. Yaz aylarında yaylacılık faaliyetleriyle beraber kış aylarında kayak tesisindeki faaliyetler gölet üzerinde bir baskı unsuru oluşturmaktadır.

Sonuç olarak, Karadeniz bölgesinde yer alan ve deniz seviyesine olan yükseklikleri farklı iki lotik sistemin (Gaga Gölü Sulak Alanı ve Çambaşı Göleti) üç dönem su kalitesi izleme sonuçları karşılaştırılan bu çalışmada, söz konusu su kaynaklarının coğrafik ve değişken iklimsel çevresel etkilerin altında kalmış olduğu, bu su kaynaklarının korunabilmesi yönünde bazı önleyici tedbirlerin alınması gerektiği ortaya çıkmaktadır.

Özellikle ötrofikasyon tehdidi altına girmiş olan Gaga Gölü Sulak Alanı için dış kaynaklı nütrient (özellikle fosfor) girdisinin azaltılması yönünde bazı program ve/veya eylem planlarının hayata geçirilmesi gerekmektedir. Deniz seviyesine olan yüksekliğin doğal su kalitelerini etkilediği gözlemlenirken, su kalitelerindeki değişimlerin de kullanım amacını ya da doğal ekosistemini etkilediği unutulmamalıdır. Rakım faktörünün çevresel açıdan göstermiş olduğu etkiler sadece su kütlerinin fiziko-kimyasal kalitelerinde değil, bu su kaynaklarından doğrudan veya dolaylı olarak faydalanan bölgede yaşayan yerel halkın bireysel veya işletme bazında sürdürdüğü tarım, balıkçılık, saz kesimi gibi farklı iş alanlarında çeşitli olumsuz etkiler gösterebilmektedir. Bu konuyla ilgili denize olan rakımsal farkın tarımsal ürünlerin üretimi ve kalitesi, balık popülasyonu ve çeşitliliği vb. ekolojik konular üzerine hali hazırda araştırmalar yapılmış ve yapılmaya devam edilmesi, bölgedeki su kaynaklarının sürdürülebilir yönetimi açısından son derece önemlidir. Su kaynaklarından verimli bir şekilde faydalanmak için, su havzasındaki kirlilik durumunu belirlemek amaciyla su kalitesinin incelenmesi ve izlenmesi, belirli zaman dilimlerinde kirlilik değişimini etkileyen önemli faktörlerin tanımlanması ve uygun tedbirlerin alınması önem arz etmektedir. 


\section{Kaynaklar}

Akkan, E., Gürgen, G. (1993). Gaga Gölü (Ordu). Ankara Üniversitesi Türkiye Coğrafyası Araştırma ve Uygulama Merkezi Dergisi, 2: 241-249

Arslanoğlu, M., Özçelik M., (2005). Sayısal Arazi Yükseklik Verilerinin İyileştirilmesi, TMMOB Harita ve Kadastro Mühendisleri Odası, 10. Türkiye Harita Bilimsel ve Teknik Kurultayı, 28 Mart - 1 Nisan 2005, Ankara.

Baron J., Schmidt T., Hartman M. (2009). Climate-induced Changes in High Elevation Stream Nitrate Dynamics, Global Change Biology 15, 1777-1789, doi: 10.1111/j.1365-2486.2009.01847.x

Bakan, G, (1995). The Study of The Sapanca Lake Ecosystems: Sediment Characterization and Water Quality Modeling. A.Ph.D. Thesis. METU, Ankara.

Bayraktar, H., Turalığlu, F. S. (2004). Atmosferik Çökelme Tayin Yöntemleri. Mühendislik Bilimleri Dergisi, 10 (1), 9-17.

Beklioğlu, M., İnce, O., Tüzün, I. (2003). Restoration of the eutrophic Lake Eymir, Turkey, by manipulation after a major external nutrient control I. Hydrobiologia, 489: 93-105.

Candan, A. Y. (2011). Gaga Gölü Sulak Alanı (Fatsa, Ordu) Fitoplanktonu ve Trofik Yapısı Üzerine Bir Araştırma. Ordu Üniversitesi Fen Bilimleri Enstitüsü, Yüksek Lisan Tezi, Ordu.

Christophoros C. ve Fytianos K., (2006). Conditions Affecting the Release of Phosphorus from Surface Lake Sediments, J. Of Environmental Quality; 35:4, 1181-1192.

Cüce H., Bakan G. (2017a). Sığ Sularda Nutrient Seviyelerine Sediman Kalitesinin Etkisinin Konumsal Olarak Değerlendirilmesi: Cernek Gölü Örneği. Türk Tarım - Gıda Bilim ve Teknoloji Dergisi, 5(5): 546-555.

Cüce H., Bakan G. (2017b). Siğ Bir Gölde Sediman Kalitesinin Trofik Duruma Etkisinin Değerlendirilmesi; Balık Gölü Örneği (Kızılırmak Deltası). Ordu Üniversitesi Bilim ve Teknoloji Dergisi, Arşiv, Cilt 7, Sayı 1.

ÇŞB, (2018) Ordu İli 2017 Yılı Çevre Durum Raporu. Çevre ve Şehircilik Bakanlığı, Çevre ve Şehircilik İl Müdürlüğü, Ordu.

Dodson, S. L., Arnott, S. E., Cottingham, K. L. (2000). The relationship in lake communities between primary productivity and species richness. Ecology, 81: 2662-2679.

EC, (2000). Directive 2000/60/EC of the European Parliament and of the Council of 23October 2000, Establishing a Framework for Community Action in the Field of Water Policy (Water Framework Directive).

Egemen, Ö. (2006). Su kalitesi. Ege Üniversitesi Su Ürünleri Fakültesi, Yayın no:14, 6. bask1, 150 s, Bornova-İzmir.

Günay, P. D. (2018). Su Kimyası ve Kimyasal Temel İşlemler. Balıkesir Üniversitesi, Mühendislik Fakültesi, Çevre Mühendisliği Bölümü, Balıkesir.

Güner, D. D. (2011). Limnoloji, İç Kullanımlar İçin Limnoloji Ders Notları (Derleme). Trakya Üniversitesi Fen Fakültesi Biyoloji Bölümü, Edirne.

Kırımker, K. (2014). Prezi Web Sitesi: Https://Prezi.com/Lg5anwywjpyx/Sularda-Sertlik/ Erişim Tarihi: Ekim 2019.

Kristensen, P., Hansen, H. O. (1994). European rivers and lakes, assessment of their environmental state. European Environmental Agency, EEA Environmental Monographs 1, 122 p.

KUDAKA (2016). Yüksek Rakım Ürünlerinin Markalaşmas1, TRA1, Kuzeydoğu Anadolu Kalkınma Ajansı, kudaka.org.tr. Erişim Tarihi: Kasım 2019.

OSIB (2017). Göller ve Sulak Alanlar Eylem Planı 2017-2023. Orman ve Su İşleri Bakanlığı, Su Yönetimi Genel Müdürlüğü, Ankara.

Pusceddu, A., Gambi C., Manini E. and Danovaro R., (2007). Trophic state, ecosystem efficiency and biodiversity of transitional aquatic ecosystems: analysis of environmental quality based on different benthic indicators, Chemistry and Ecology, Vol. 23, No. 6, 505-515

Raicevic V., Bozic M., Rudic Z., Lalevic B. ve Kikovic D., (2011). The evolution of the eutrophication of the Palic Lake (Serbia), African Journal of Biotechnology Vol. 10(10), pp. 1736-1744. 
Royal, G. (2016). Rosuarıtma. Web Sitesi: hHttps://Rosuaritma.com/Iletkenlik-Ve-Tds-Nedir, / Erişim Tarihi: Mayıs 2019.

Taş, B. (2006). Derbent Baraj Gölü (Samsun) su kalitesinin incelenmesi. Ekoloji, 15(60): 1-6.

Taş, B. (2016). Phytoplankton community and ecological state of a high-mountain lake within an Important Natural Area (Eastern Black Sea, Turkey). Fundamental and Applied Limnology, 189/1, 51-61.

Taş, B., (2011). Gaga Gölü (Ordu, Türkiye) Su Kalitesinin İncelenmesi., Karadeniz Fen Bilimleri Dergisi, İlkbahar 2 Cilt, Vol: 1 Say1: 3(1), Sayfa 43-61.

Taş, B., (2012). Diversity of Phytoplankton and Trophic Status in the Gaga Lake, Turkey. Energy Education Science and Technology Part A: Energy Science and Research, 30(1): 33-44.

Taş, B., Candan, A.Y., Can, Ö., Topkara, S. (2010). Ulugöl (Ordu)'ün bazı fiziko-kimyasal özellikleri. Journal of FisheriesSciences.com, 4(3): 254-263.

Taş, B., Kolören, Z. (2017). Evaluation of water qualities of discharging area of some running waters into Black Sea in the Central Black Sea Region of Turkey. Review of Hydrobiology, 10(1): 1-19.

Taş, B., Tepe, Y., Ustaoğlu, F., Alptekin, S. (2019). Benthic algal diversity and water quality evaluation by biological approach of Turnasuyu Creek, NE Turkey. Desalination and Water Treatment, 155: 402415.

Tepe, Y., Boyd, C.E. (2003). A reassessment of nitrogen fertilization for sunfish ponds. Journal of World Aquaculture Society, 34 (4), 505-511.

Topkara, S. (2011). Çambaşı Göleti (Kabadüz, Ordu) Fitoplanktonu ve Trofik Yapısının İncelenmesi. T.C. Ordu Üniversitesi Fen Bilimleri Enstitüsü, Yüksek Lisans Tezi Biyoloji Anabilim Dalı, Ordu.

Tsagli J. A., (2006). Spatial Distribution of Water Quality and Eutrophication Levels of Wetlands; A Case Study of Lake Cuitzeo-Mexico, A Thesis for The Degree of Master's of Science (Supervisor: Vekerdy Z.) International Ins. for Geo-Information Sci. and Earth Observation, NL. 